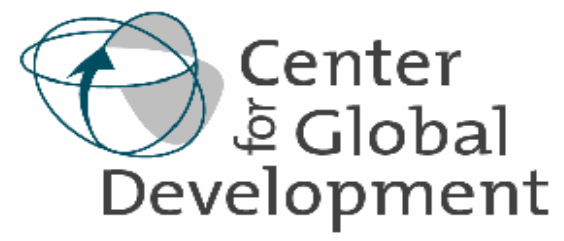

Abstract
The Millennium Development Goals (MDGs) are unlikely to be met by 2015,
even if huge increases in development assistance materialize. The MDGs are a set of
quantitative, time-bound targets for indicators such as poverty, education and
mortality in developing countries adopted unanimously by the UN in 2000 . However,
the rates of progress required by many of the goals are at the edges of or beyond
historical precedent. At the same time, there appear to be limits to the degree to
which aid can contribute to development outcomes. Estimates of the 'cost' of
reaching the MDGs are nevertheless frequently misinterpreted to mean that a certain
quantity of aid-such as the oft-cited $\$ 50$ billion-could cause the Goals to be met.
Despite many benefits of the MDGs, there has been little discussion so far of
potential costs of the specific form taken by these goals, especially the creation of
unreasonable expectations about what is achievable in a short time frame and about
the role of aid in the development process. Many countries making extraordinarily
rapid progress on MDG indicators, due in large part to aid, will nonetheless not reach
the MDGs. Unrealistic targets thus may turn successes into perceptions of failure,
serving to undermine future constituencies for aid (in donors) and reform (in
recipients). This would be unfortunate given the vital role of aid and reform in the
development process and the need for long-term, sustained aid commitments.
Though goal-setting can be useful, these particular goals might be better viewed not
as practical targets but instead as valuable reminders of the stark contrast between
the world we have and the world we want, and as a call to redouble our search for
interventions to close the gap more rapidly.

\section{Working Paper Number 40 \\ May 2004 \\ Revised September 2004}

\section{The Trouble with the MDGs: Confronting Expectations of Aid and Development Success}

By Michael A. Clemens, Charles J. Kenny,

Todd J. Moss

Abstract
The Millennium Development Goals (MDGs) are unlikely to be met by 2015,
even if huge increases in development assistance materialize. The MDGs are a set of
quantitative, time-bound targets for indicators such as poverty, education and
mortality in developing countries adopted unanimously by the UN in 2000 . However,
the rates of progress required by many of the goals are at the edges of or beyond
historical precedent. At the same time, there appear to be limits to the degree to
which aid can contribute to development outcomes. Estimates of the 'cost' of
reaching the MDGs are nevertheless frequently misinterpreted to mean that a certain
quantity of aid-such as the oft-cited $\$ 50$ billion-could cause the Goals to be met.
Despite many benefits of the MDGs, there has been little discussion so far of
potential costs of the specific form taken by these goals, especially the creation of
unreasonable expectations about what is achievable in a short time frame and about
the role of aid in the development process. Many countries making extraordinarily
rapid progress on MDG indicators, due in large part to aid, will nonetheless not reach
the MDGs. Unrealistic targets thus may turn successes into perceptions of failure,
serving to undermine future constituencies for aid (in donors) and reform (in
recipients). This would be unfortunate given the vital role of aid and reform in the
development process and the need for long-term, sustained aid commitments.
Though goal-setting can be useful, these particular goals might be better viewed not
as practical targets but instead as valuable reminders of the stark contrast between
the world we have and the world we want, and as a call to redouble our search for
interventions to close the gap more rapidly.




\title{
The Trouble with the MDGs: Confronting Expectations of Aid and Development Success
}

\author{
Michael A. Clemens, Charles J. Kenny, and Todd J. Moss* \\ Washington DC \\ May 2004 \\ Revised Version: September 2004 \\ Prepared as a Working Paper for the Center for Global Development
}

\footnotetext{
* Michael Clemens (mclemens@cgdev.org) and Todd Moss (tmoss@cgdev.org) are Research Fellows at the Center for Global Development. Charles Kenny (ckenny@worldbank.org) is a Senior Economist at the World Bank. We thank Alicia Bannon for excellent research assistance, and Colin Bradford, Bill Cline, Kim Elliot, Maureen Lewis, Steve Radelet, David Roodman, Markus Scheuermaier, Peter Timmer, Kelly Tobin, Jeremy Weinstein, and John Williamson for helpful comments on an earlier draft. All judgments, opinions, and errors are those of the authors alone and do not represent the views of the Center for Global Development, the World Bank, or either of their respective staffs or boards of directors, nor the countries that the Executive Directors of the World Bank represent.
} 
"The Millennium Development Goals are not just wishful thinking. They are certainly ambitious, but they are also technically feasible."

—Kofi Annan, Nov 6, 2003.

"There is a real danger that the MDGs will be remembered as false and empty promises."

-Action Aid, 2002

In September 2000 at the United Nations, 147 presidents, prime ministers, and monarchs - the largest-ever gathering of heads of state-unanimously adopted the Millennium Declaration, committing themselves to a series of international development objectives to be reached by $2015 .{ }^{1}$ Known since 2001 as the Millennium Development Goals (MDGs), these eight goals (with eighteen targets and 48 specific indicators) are widely cited as the primary yardstick against which advances in international development efforts are to be judged. ${ }^{2}$ The official MDG website says that the goals "have been commonly accepted as a framework for measuring development progress."3

After the MDGs were established, calculating what kinds of resources and actions would be necessary to reach them became a priority. There are now several "costing" studies, estimating how much money would be required to reach the goals. In addition to other conditions, such as higher economic growth and the improved economic policies, these studies have concluded that something in the range of $\$ 40-70$ billion in extra resources each year will be necessary. Fifty billion dollars is the most commonly cited figure for new annual aid requirements.

Nearly four years after setting the MDGs, it appears that the global goal of halving poverty may soon be reached because of rapid progress by the two population giants of India and China. ${ }^{4}$ However, it appears almost certain that the majority of developing 
countries will not meet the country level poverty targets set by the Millennium Declaration, nor many of the other goals. And some whole regions, especially subSaharan Africa, will miss them by a wide margin. Of the 47 African countries, 42 are considered "off track" for at least half of the targets and 12 are "off track" for all targets. Meeting the goals for the majority of country indicators would require more than doubling the rate of progress (Carceles et al. 2001). Bruns et al. (2003) estimate that 86 out of 155 countries are at risk of not achieving the goal of universal primary education. Twenty-seven of these countries are not even expected to break the 50\% completion threshold by 2015. These forecasts exclude the 16 developing countries with no data-all of which are likely to have extremely low indicators. The UNDP (2003) estimates that, on current rates of progress, sub-Saharan Africa would not meet the hunger, primary education and child mortality targets for at least another century.

This apparently bleak state of affairs is already leading to complaints that the rich countries are not living up to their end of the MDG bargain. ${ }^{6}$ The eighth goal commits rich countries to a global partnership for development, wherein they promise to allow greater trade access, reduce debts, and increase aid. Although there has been substantial progress in debt reduction, rich country trade policies have not significantly changed to be more favorable to developing countries, notably on agricultural market reform. Furthermore, the estimated levels of mobilized resources required have not been forthcoming from donors. Total official development assistance (ODA) from the main international donors ${ }^{7}$ was $\$ 53$ billion in 1999 and this figure rose to just $\$ 57$ billion in 2002, far from the doubling of aid called for by a range of costing studies. If many of the 
MDG targets are formally missed in 2015, will we be able to point to the failure of donors to provide resources as the main culprit?

This paper briefly summarizes the conclusions of some of the better-known MDG costing studies. It also reports on the caveats that most such studies include. The paper goes on to evaluate the importance of those caveats, starting with the poverty goal and moving on to discuss some of the most prominent quality of life indicators, including achieving universal primary education (goal two), eliminating gender disparities (goal three), reducing child mortality (goal four), and improving maternal health (goal five). As a result of a review of some of the historical evidence regarding progress in the indicators underlying the MDGs, the paper concludes with three arguments: Many of the goals are simply unrealistic for many countries; costing studies are frequently misinterpreted and have contributed to an excessive focus on donor resources; and there is a real risk that the MDGs_-as currently conceived and promoted_could turn development successes into failures.

We begin by surveying the clearest example of how the MDGs have been interpreted: the studies estimating their 'cost'. These studies are frequently taken to imply that a sufficiently large amount of aid would be sufficient to cause a rapid acceleration in historical performance. In the sections thereafter we argue that the historical record and numerous studies on the relationship between inputs and outcomes present a serious challenge to that interpretation. 


\section{How the MDGs have been interpreted}

The MDGs began as a review of development policy by the OECD's DAC in the mid 1990s. They first appeared in print in 1996 as recommendations in the OECD’s booklet Shaping the 21 $1^{\text {st }}$ Century: The Contribution of Development Cooperation. These ideas evolved over the subsequent years into a set of "international development goals" by 2000. ${ }^{8}$ On September 08, 2000 all 189 UN Member States approved the UN Millennium Declaration, which committed them to meeting the MDGs by 2015 (see Appendix Table A-1 for a list of the goals and targets).

From the beginning, the MDGs were linked to the need for greater donor financing. ${ }^{9}$ The OECD states bluntly, "Development costs money.... the high-income countries need to supply more aid.”10 The UN's Monterrey Consensus proclaimed that "a substantial increase in ODA and other resources will be required if developing countries are to achieve the internationally agreed development goals” (UN 2002).

The first answer to the question 'how much?' was a study led by former Mexican President Ernesto Zedillo and known as the "High-level Panel on Financing for Development” (2001). The study estimated that to reach the MDGs an additional \$50 billion per year in ODA would be needed, plus $\$ 3$ billion more in humanitarian aid, and about $\$ 15$ billion more for "global public goods." This brings the total of additional resources to at least $\$ 68$ billion, or slightly more than doubling current levels of aid. 
A second widely cited study by Devarajan, Miller, and Swanson of the World Bank uses two estimates for costing the MDGs (Devarajan et al. 2002). First, it calculates the additional resources necessary to increase economic growth so as to reduce income poverty. For this it suggests a "financing gap" of \$54-62 billion each year. Second, it estimates the cost of meeting specific goals in health, education and environment by using country-specific unit costs and then multiplying by the uncovered population. By this method it finds that $\$ 35-75$ billion more per year are needed. Based on these two methods, the paper concludes that ODA increases in the range of $\$ 40-70$ billion are required. Again, this is an approximate doubling of official aid flows, roughly confirming the Zedillo estimate. These numbers have been directly influential on major policy proposals; they were used, for example, as the basis for a 2003 plan by the UK Treasury to increase current global foreign aid by $\$ 50$ billion by selling future aid flows to financial markets through an International Finance Facility. ${ }^{11}$ The figure is also commonly cited by NGOs and other aid advocates. ${ }^{12}$

A series of other papers have tried to quantify the costs of meeting the MDGs for particular regions, countries, or for meeting an individual goal. Some of the most commonly cited studies are summarized in Table 1 . Of note, and relevance for later sections of this paper, are the various estimates for costing universal primary education (UPE) or Education for All (EFA), including \$9 billion per year (Delamonica et al. 2001, for Unicef) and \$10-15 billion (Devarajan et al. 2002). 
The costing methods used in these studies are by necessity, and usually by the authors' own admission, simple and approximate. "It is clear that our present knowledge does not suffice to put a convincing price tag, even a rough one, on the cost of meeting the human development goals. Individual economies have not yet started to estimate the costs of meeting the goals, as they need to do if credible worldwide estimates are to be made available,” notes the Zedillo study (p.69). “...[T]hese estimates are extremely crude, and based on a host of heroic assumptions, many of which may not be borne out as history unfolds” point out Devarajan et al. (p.30). ${ }^{14}$

Most of these studies (but by no means all of them) are extremely careful to clarify that the resulting estimates are imprecise and also that several caveats apply to their conclusions. "[W]e cannot stress enough the fact that financial assistance is but one of the factors required to reach these goals" state Devarajan et. al (2002, p. 30). The two most commonly cited caveats, and perhaps the most important, are (a) the policy environment within developing countries considerably improves, and (b) that current bottlenecks and capacity constraints are substantially relieved.

Regarding policies, the Zedillo study, for example, assumes that recipients are doing "what's necessary" to improve policies. Mingat et al. (2002), in looking at the costs associated with reaching universal primary education for 33 African countries, state that "the implicit assumption is that countries would reform their education sector policies as needed to ensure that resources are used to offer quality services in a cost-efficient 
manner” (p. ix). Oxfam (2002) suggests that local political commitment would be required (p. 9).

Looking at absorptive capacity and other administrative bottlenecks, it is usually assumed that these are relieved. Mingat et al., for example, note that "[f]or the sake of simplicity, we set aside at this stage the physical feasibility of the EFA-by-2015 objective. We focus instead on the size of the financing gap...” (p. 1). The Devarajan paper is also predicated on the idea that the question to be answered is 'if we achieved the MDGs by 2015, how much would it have cost?'- explicitly leaving aside the question of developing countries' capacity to spend effectively such sums. They specifically note the capacity dilemma faced in particular by countries outside of Asia (see also Heller and Gupta 2002).

Again, most of the authors of costing studies are quick to point out that these caveats are significant, and that the findings that result from their exercises are both very approximate and highly contingent. Despite these careful qualifications, many in the policy, advocacy and media world have inappropriately focused attention on the bottom line figure: $\$ 50$ billion more in aid is needed to achieve the MDGs. The misuse and misinterpretation of the costing studies has added to the impression that resources and aid flows are the critical or even sole determinant of development outcomes.

The UK's Chancellor of the Exchequer Gordon Brown, a prominent proponent of increased aid flows, has proposed an International Finance Facility that is explicitly based on the costing studies and makes the link between more ODA and meeting the MDGs. 
An IFF briefing note explains "Estimates suggest that development assistance must be doubled and focused on the poorest countries is the Millennium Development Goals are to be met—an increase of at least $\$ 50$ billion a year.” Elsewhere, Brown has been even more explicit that:

...the key question is how we can meet in practice the ambitious Millennium Development Goals. If every child is to have primary education, we will need $\$ 10$ billion dollars more a year. If infant mortality is to be cut by two thirds and maternal mortality by three-quarters, we will need at least $\$ 15$ billion extra a year. If we are to halve poverty by 2015 we will need an additional $\$ 20$ billion or more each year. ${ }^{15}$

By juxtaposing the question of how to meet the goals "in practice" with a list of concrete dollar amounts, Brown implies that massive spending is a practical way to meet the goals. Similar statements from other leaders of the aid community are commonplace.

The main section of this paper discusses the links in the chain of causality between increased aid flows and attaining the MDGs, and suggests that the caveats mentioned by study authors are indeed very significant—perhaps so significant that the MDGs are unlikely to be reached regardless of new aid flows. The paper examines several specific MDGs and in greater detail to highlight some of these issues. In each case, it appears that many countries are very likely to miss the MDG targets, that rapid progress is nonetheless being made, and that the role for increased financing to accelerate trends has a limit.

\section{Reaching Goal One: Halving Poverty}


The first MDG is to halve the 1990 poverty headcount by 2015. On a global scale, this goal is very likely to be reached, almost entirely because of poverty reduction in fastgrowing India and China. ${ }^{16}$ At the same time, the majority of individual countries appear very unlikely to halve poverty by 2015 because the economic growth are extremely high by historical standards. At the same time, it is doubtful that increased aid would sufficiently accelerate growth rates, especially in the countries that are currently most offtrack to miss the poverty reduction target. Methodologically, most of the costing exercises use the 'financing gap' to calculate the additional aid required for meeting growth targets, but this approach is problematic and raises further doubts about the estimates.

Economic growth is central to the poverty reduction goal because it is the only source of increased income for the poor that can be (comparatively) rapidly achieved. Poor people in developing countries can become wealthier either through receiving a greater share of existing national income (redistribution of wealth from rich to poor) or a similar share of a greater national income (equitable economic growth). However, it is historically very rare to see rapid changes in income inequality (up or down) over time, and so those countries that have achieved rapid and substantial poverty reduction have done so mainly through economic growth. Dollar and Kraay (2001) suggest a one-for-one relationship between average income growth and the income growth of the bottom $20 \%$. Besley and Burgess (2003) suggests that the elasticity of poverty with respect to income per capita varies between -0.49 in Sub-Saharan Africa to -1.14 in Eastern Europe, with a developing country average of -0.73 . Regardless of the precise elasticity, it is clear that 
to achieve meaningful poverty reduction, economic growth rates will have to accelerate in the countries where the poor reside.

The World Bank (2004a) suggests that the typical African country will need to grow on average at least $7 \%$ for the next 15 years in order to halve poverty rates. ${ }^{17}$ This compares to an average regional growth rate of just $2.4 \%$ for the past 15 -year period. Of the 47 sub-Saharan countries only two, Botswana and Equatorial Guinea (combined, representing less than $0.3 \%$ of the continent's population), have grown at the $7 \%$ rate over this period. Among African countries, nearly half (21) have seen negative per capita growth, and only nine (mostly small) countries have been above $2 \%$. As a result, the poverty headcount ratio in Africa has actually increased, from $47 \%$ in 1990 to $49 \%$ in 2000. And it is not just that high rates of growth are unusual for Africa; in the world as a whole, between 1985-2000 only five countries managed to sustain a 7\% growth average (calculated from World Bank, 2004c).

Figure 1 reveals the stark contrast between UN goals and performance in LDC growth measured by the Penn World Table. The UN General Assembly resolutions declaring the second and third "development decades" — the 1970s and 1980s—gave explicit goals for average real annual growth in GDP and GDP per capita in developing countries: 3.5\% and $4.5 \%$, respectively. In both cases, population growth was assumed to be $2.5 \%$ per year. The UN declarations for the first and fourth "development decades"- the 1960s and the 1990s — give only targets for GDP growth, but we can approximate the implied GDP per capita growth rate by assuming roughly the same rate of population growth of $2.5 \%$. 
This means that the First Development Decade goal of 5\% GDP growth implies roughly $2.5 \%$ in per capita growth, and likewise implies that the Fourth Development Decade goal of $7 \%$ in GDP growth implies $4.5 \%$ in per capita GDP growth. Comparing all of these targets to actual LDC performance in the latter three decades of the twentieth century shows an arresting pattern. Every decade or two since the 1960s, the UN has increased its goal for developing country growth by $1 \%$. Meanwhile, growth in LDCs has not changed very much. This "goal inflation" has now arrived at the point where what is expected of LDCs lies at the very extreme of the distribution. Decades after the first round of goals, we still do not know how to turn Zambia into Botswana, nor how to turn Laos into Korea.

In the costing studies cited above, the expectation that unusually rapid growth rates might now be achieved more widely is based on two assumptions: (a) that policy changes will foster growth and (b) that increased aid in the presence of those good policies will catalyze even faster growth. There are problems with both of these assumptions, however. Easterly (2003a), reviewing evidence of the link between aid and outcomes, concludes that aid agencies "have misspent much effort looking for the Next Big Idea that would enable aid to buy growth.”

There is an ongoing debate between development economists who believe that policies are the major determinant of economic growth performance and those who believe that structural factors such as geography, history, and climatic conditions may play the dominant role. It may be fair to summarize that the evidence linking structural factors 
that do not change over time to growth is at least as strong as the evidence linking policies to changes in growth performance-in part because structural factors help drive policy choices, in part because of an independent direct impact. ${ }^{18}$ It is also worth noting that cross-country evidence is not terribly clear on which policy levers might be the important ones for economic growth. As relevant, policy change has been historically slow and frequently reversed. Easterly et al. (1993) find policies far more stable than growth rates over time. The combination of a limited role for free policy choice in determining growth rates and limited evidence that dramatic improvements in policy stances are common suggests that the role for policy change to speed growth over the next fifteen years may be only modest.

There is further caution required regarding the link between increased donor assistance and higher economic growth. This assumption underlies all of the costing studies which use the 'financing gap' model for estimating how much aid will be needed to reach certain growth targets. These estimates start from a measurement of poverty-income elasticity and current growth rates, which suggests a "growth gap"-the rate at which the economy must grow to see the desired reduction in the poverty headcount—or in the case of reaching the poverty MDG, to halve the poverty ratio by 2015. This approach then uses the incremental capital output ratio (ICOR) to calculate what level of investment is required to reach the growth levels, then subtracts domestic savings to get the external financing gap—or the amount of required aid. 
The problem is that, in practice, the financing gap model does not appear to work. Easterly (1999) demonstrates weak relationships in developing countries all along the aid-to-investment-to-growth chain. If the financing gap approach had worked as expected over the period 1960-1994, he calculates that Zambia’s per capita income would have been $\$ 20,000$, or 33 times the actual figure of about $\$ 600$ (Easterly, 2001, p. 43).

One recent and more positive contribution to the aid and growth literature is Burnside and Dollar (2000). This highly influential study has been used to make the case that aid can lead to growth under the right circumstances—including the policy environment assumed by many of the costing studies. The results of Burnside-Dollar appear to be somewhat fragile — changing the period, adding new country data, or altering the definitions of 'aid' or 'good policies' tend to weaken the results (Easterly, Levine, and Roodman 2003; Hansen and Tarp 2001; Lensink and White 2001; Guillamont and Chauvet 2001). Cassen’s conclusion some ten years ago still seems to hold: "Inter-country statistical analyses do not show anything conclusive—positive or negative—about the impact of aid on growth. Given the enormous variety of countries and types of aid this is not surprising.... If such a relationship does not emerge overall, it only shows the unexciting conclusion that aid may or may not be strongly related to growth, depending on circumstances” (1994). More recently, Clemens, Radelet and Bhavnani (2004) have found striking evidence of a positive average effect of development aid on growth, once the type of aid analyzed is matched to the time horizon of its expected growth effect. While this effect is clear on average, it varies greatly by country and its magnitude is 
limited to a certain range - two reasons to question whether even unlimited aid could cause a particular high level of growth in any given country.

It seems plausible to assume that the relationship between aid and growth in the presence of good policies does hold, at least under some circumstances. Does this suggest that significant increases in aid are likely to help meet the poverty MDG? The answer is still uncertain. This is because most low-income countries where the poor reside either have poor policies and weak institutions (and thus are assumed unable to use additional aid effectively) or already receive considerable amounts of external assistance. This second factor may be a problem because even work that accepts a link between aid and growth finds that, above a certain level of aid, the relationship begins to break down (Collier and Dollar 2000). ${ }^{19}$ Many poor countries already thought to have 'good policies' already receive substantial aid. Mozambique, for example, receives ODA more than twice the level of its domestic tax base. Other top-performing countries—such as Ghana, Ethiopia, Uganda, Nicaragua, Honduras, Burkina Faso, and Tanzania—receive aid flows well above $10 \%$ of GDP. Were total ODA levels to be doubled, as called for in the costing studies, the countries that are perhaps best able to absorb large aid increases are India and China, which currently receive minimal aid ( $0.36 \%$ and $0.13 \%$ of GDP, respectively). However, these two countries are both considered "on track." ${ }^{20}$ The MDGs do not change the oft-noted irony of aid: those that need it most are frequently the ones least able to use it effectively. ${ }^{21}$ 


\section{Reaching the Social Sector Goals}

We turn now to the social sector indicators included in the MDGs.

There is already a large literature on the complex relationships between conditions, interventions, and outcomes, but this appears to have been somewhat neglected by the public discussion of the MDGs. For example, when it comes to most health or education variables, at a single time they are quite closely related to income (Pritchett and Summers 1996). However, over time, progress on these indicators as well as many others tested by Easterly (1999) are not correlated with the rate of growth in that country, but instead with improvements over time common to all countries. ${ }^{22}$ Given this, it may be difficult to considerably speed that progress through policy changes or alteration in resources.

Adding to the complexity of the causal chain between expenditures and outcomes is the fact that certain sector interventions can have impacts on other sector outcomes. Kremer and Miguel (2001), for instance, found that de-worming programs had a strongly positive impact on school attendance in Kenya. Ranis and Stewart (2001), who found that health expenditures appeared to have little or no impact, did suggest that increased female primary enrollment had an impact on life expectancy. Hicks (1982) also found that variations of life expectancy were insignificantly correlated with measures such as population per doctor and overall income per capita changes, but significantly related to literacy and inequality.

All of this suggests that (a) additional aid may not be the most important factor in improving social outcomes; (b) the sectoral distribution of aid to maximize progress on 
any particular social MDG is not clear; (c) unit-cost approaches utilized in costing studies may be dramatically misleading; and (d) 'best practices' may not be easily exportable because they are dependent on a range of determining factors that may be difficult to replicate. Of course, some of the costing study authors have suggested such problems themselves ${ }^{23}$, but this has not stopped the widespread misinterpretation of their work.

To better illustrate these arguments and the weaknesses in the costing approach to the MDGs, we turn now to the specific social sector goals and the historical record, focusing mainly on the second MDG of achieving universal primary education and, briefly, touching on the other goals.

Goals Two and Three: Universal completion of primary school and Gender Equality in Education $^{24}$

Over the decades, rates of primary enrollment and completion have risen nearly everywhere - even in many of the very poorest countries — and they have risen at remarkably uniform rates. Figure 2 gives an overview of what happened to enrollments between 1960 and $2000 .{ }^{25}$ The figure answers the following question: If we were to make the assumption that the growth of primary enrollment across time in all countries followed the same pattern, based on one particular S-shaped curve (or "logistic" curve), what would that curve look like? The figure takes the path that each country followed during those four decades, and lines up each country individually so that, if following that single curve, it would have hit the 50\% enrollment mark in the same year-“adjusted year” zero. 
Two things jump out from the graph. First, our assumption is not that bad; countries' idiosyncratic paths from low to high enrollment cluster remarkably closely around a single S-curve, whose slope at the halfway mark (or "transition speed") is about 0.04 . There is variation around the curve, but remarkably little given that the countries there include tropical and arctic, rich and poor, socialist and capitalist, war-torn and peaceful. Second, the slope of the curve, or the "typical" transition speed from low to high enrollment, is low compared to growth rates required to meet the MDG target. While the extension of mass schooling in the latter half of the $20^{\text {th }}$ century was vast, it also took a long time. If it started at 50\% enrollment, the typical country—rich or poor-would have risen to $70 \%$ after 22.3 years, $80 \%$ after 36.4 years, and $90 \%$ after 57.7 years.

Figure 3 shows that for the 90 countries for which we have data-representing a very broad range of wealth and institutional, political, and geographic conditions—no country has a transition speed above 0.13 , the rate required to increase enrollment from $80 \%$ to 95\% over a fifteen year period. There are 38 countries in this data set that have 2000 enrollment rates below 80 percent. For these countries (and others for which we do not have data), reaching 95 percent enrollment by 2015 (still short of the MDG target) will require historically unprecedented rates of progress.

It appears unlikely that many countries will even manage to approach the 0.13 transition rate. One reason for, or at least a related phenomenon to, the strong historical determinism of primary enrollment growth rates is the strong relationship between 
parental primary completion and child enrollment. This correlates with more than ten times the amount of cross-country variation in transition speeds than does education spending. A second factor that explains cross-country variance in the transition speed with ten times the strength of differences in education expenditures is income. This all suggests a significant 'demand side' element to primary education, with wealthier, educated, parents far more willing to send their children to school. Filmer (2004) estimates that even if all rural people in a sample of 22 countries lived right next door to a school, enrollment rates would only increase from an average of 49.8 percent to 53.1 percent—suggesting the dominance of 'demand-side constraints.' Across countries, there is no significant relationship between public spending per child on education and the primary school completion rate once income is controlled for (World Bank 2004b).

Given that education expenditures do not appear to be a particularly strong historical determinant of enrollment, given not all countries will grow rapidly, and given it is very hard, in a fifteen year period, to dramatically increase parental primary completion rates, it is unlikely that many countries will achieve high transition speeds. Indeed, even most 'exceptions to the rule' or 'best practices' of rapid increases are, sadly, related to unique circumstances, considerable reductions in quality, or questionable data (Clemens 2004).

Turning to gender equality in education, Figure 4 shows the path taken by the female-tomale ratio in gross primary enrollments, for all 168 countries in the UNESCO database since 1950. The figure is constructed in a manner identical to that of Figure 2. Once again we see that, the assumption that all countries follow the same S-shaped path to gender 
parity is not strictly true but neither is it far from the mark and the typical country has taken a long time to reach gender parity in primary school enrollment. The shape of the curve in Figure 4 suggests, for example, that a country whose ratio of girls' gross primary enrollment to boys' is 0.8 typically takes 28 years to reach a ratio of 0.95 . In the year 2000, 17 countries had a ratio of less than 0.8. Nevertheless, the great majority of developing countries are already fairly close to meeting the MDG target of gender equality in education. ${ }^{28} \mathrm{~A}$ substantial majority of countries will likely reach this particular goal by 2015. The use of static unit costs in education estimates, as used in the costing studies is therefore likely to ignore perhaps the most important determinants of enrollment. ${ }^{29}$

\section{Goal Four: Reducing child mortality by two-thirds}

In the fourth MDG, governments have committed themselves to reducing child mortality by two thirds between 1990 and $2015 .{ }^{30}$ Assume, as we did for education, that infant mortality follows an S-shaped curve, in this case in which countries start out at some historically high level and fall toward some new level at a rate that is proportional to the current level. Next, assume (again as we did with the education goals) that every country follows the exact same S-curve-in this case towards zero infant mortality—but (again) that each country goes through this transition at a different time.

These assumptions once more appear reasonably robust. Figure 5 shows what happens if we take data for 35 rich and poor countries covering roughly the $20^{\text {th }}$ century, assume that the historically highest level was 350 infant deaths per 10,000 live births, and 
horizontally align all the series so that every country passes through $50 \%$ of the maximum - that is, 175-in the same year (“adjusted year" zero). The lessons are familiar from the previous two sections. Immediately we see that (1) there is remarkably little diversity in the rate at which this has occurred, and (2) the typical experience of a country in the $20^{\text {th }}$ century was that this transition was slow as compared to the MDG target decline. The slope of the S-curve running through the middle of the cloud, representing the experience of the 'typical' country among these 35 , is -0.0339 at the inflection point. That means that a country typical of this group, if it started out at 100 infant deaths per 10,000 live births, would take 40 years to decrease this level by two thirds. This figure is relatively insensitive to the starting level.

Nor has the story dramatically changed in the late $20^{\text {th }}$ century, despite technology advance. Although technological and economic advances allowed for far lower infant mortality rates essentially everywhere in the late $20^{\text {th }}$ century, the speed at which countries made the transition from high to low infant mortality did not change significantly. If we now restrict the sample to the years 1980-2000, and consider all 176 countries for which the World Development Indicators provide infant mortality rates, the slope of the S-curve is -0.0324 at the inflection point. A typical country in this group of 176, starting from an infant mortality of 100 , would take 42 years to lower this figure by two thirds. ${ }^{31}$

To be more specific, let us imagine that the fourth MDG had been set in 1975-to reduce child mortality by two thirds in the quarter century leading up to 2000 —and compare this 
goal to what actually happened. Figure 6 shows that of the 109 countries for which we have data, 33 would have met our hypothetical goal of decreasing child mortality by twothirds in 25 years. At the same time, of those countries that achieved a two thirds reduction in child mortality over the 1975-2000 period, none were amongst the poorest. Only one country with an income below $\$ 1,600$ in 1975 reduced child mortality by two thirds over the next 25 years: Indonesia. This is not to say that the period 1990-2015 must exactly replicate the experience of the period 1975-2000. It does point out that we have the experience of only one country with an income of below \$1,600 in 1975 to offer as a model to countries in that income bracket today trying to replicate such an achievement. Unfortunately, we return to the same theme: setting aside the uniquely favorable conditions in Indonesia, widespread achievement of the fourth MDG has no recent precedent in poor countries.

This suggests that the forces that primarily determine the speed of this transition go beyond public health policy and inputs—a conclusion supported by a number of different studies. Health outcomes are not related to expenditures (Filmer et al. 2000). Across countries, there is no significant relationship between public health spending per capita and under five mortality once income is controlled for (World Bank 2004b, see also Hanmer and White 1999; Thorbecke and Charumilind 2002). Indeed, 95\% of the variation in child mortality across countries can be explained by national income and its distribution, female literacy, ethnolinguistic fractionalization and the predominant religion of the country (Filmer and Pritchett 1999). It appears that one of the reasons that interventions often do not have the desired outcome is—as Pritchett (1994) showed with 
the relative ineffectiveness of family planning aid-that supply-side responses do not address the demand component that are affected by broader social and economic changes And income, inequality, literacy, ethnic makeup and religion are all factors slow to change, at least within a fifteen-year perspective.

None of this is to say that specific public health interventions and large injections of inputs purchased by aid cannot affect infant mortality; obviously they can. Hanmer et. al (2003) suggest that while income per capita, education and gender inequality are all robust determinants in explaining infant and child mortality across countries at a single

time, some health spending (particularly on immunization programs) can also have a significant impact, for example. Rather, it is to question whether the rapid increase in the mortality transition rate needed to meet the fourth MDG is accessible to even the wisest and best-funded policy interventions.

\section{Goal Five: Reducing maternal mortality by three quarters}

In the fifth MDG, the world's governments committed themselves to reducing the maternal mortality rate (MMR) by three quarters between 1990 and 2015. MMR is the number of maternal deaths per 100,000 live births. Reliable international figures on MMR have only begun to be gathered relatively recently, and those that do exist contain a significant margin of error. Nonetheless, we can use the existing numbers with all of their imperfections to get a broad idea of how quickly the transition from high to low maternal mortality has been occurring in most countries. 
We do not have the 25 years of data on MMR that we would need in order to conduct exactly the same exercise here that we did for child mortality. The World Health Organization’s internationally comparable statistics begin in 1990 and were updated in 2000. But we can ask how many countries were making the transition during the 1990s at an annual rate that, if continued for 25 years, would be sufficient to meet the fifth MDG. This rate is an annual decrease of 5.39\% in MMR.

Figure 7 suggests the answer. Average rates of change in MMR have been slow compared to the rates of progress required to meet the MDG target. ${ }^{32}$ A good number of countries have managed a rate of progress that, if sustained over the next fifteen years, would allow them to meet MDG targets. Sadly, about as many have seen increases in maternal mortality rates over the course of the 1990s. Furthermore, as with infant and child mortality, progress has been faster in wealthier countries. The median annual rate of decrease in maternal mortality for all 140 countries in the figure was $2.10 \%$. Among the 42 countries below $\$ 1,600$ GDP per capita, only seven were able to reduce maternal mortality during the 1990 s at the annual rate of $5.39 \%$ required by the fifth MDG (the upper-left quadrant of the figure), and the median annual decrease was $1.15 \%$. In other words, the rate of change in MMR called for by the fifth MDG requires a quintupling — or more- of the rate that MMR has been changing in most poor countries. These broad conclusions are robust even to substantial measurement error in the MMR figures. In countries richer than $\$ 1,600$ GDP per capita, the median rate of decrease was $3.20 \%$. 
Of further concern is that rapid progress over the last decade appears to have been concentrated amongst countries with the highest MMR rates at decade-start. All seven of the poor countries in Figure 7 that progressed at rates compatible with the goal began the 1990s with an MMR over 850. Of all 124 countries for which we have data that started out the decade with an MMR lower than 850, not one was able to reduce MMR at the rate envisioned in the fifth MDG. The declines in MMR managed by many countries which started the decade with MMR rates of above 850 is laudable, and suggests significant development progress. However, it may be that these countries were able to seize upon the high-return public health interventions most accessible to changes in policy to achieve that result. If this is the case, sustaining a similar rate of progress in the future will be more complex, and even fewer countries will be able to continue reducing MMR at rates high enough to meet the MDG target.

We can say less regarding the potential impact of increased donor resources and the applicability of the unit-cost approach to the MMR goal than we can with other goals, in part because less data is available. Shiffman's (2000) work suggests some hope, here. His regression results suggest that health expenditures as a percentage of GDP and (more significantly) the percentage of women receiving trained assistance at child-birth join female secondary school enrollment in being able to explain 90 percent of the crosscountry variation in MMR. Nonetheless, given the demands for a pace of change that is rapid by historical standards, the MDG regarding maternal mortality may be missed by most countries regardless of increased expenditure by developing country governments and donors. 


\section{Leaps forward?}

It is not that we cannot imagine a scenario where historically unprecedented progress is made in Millennium indicators. If effective preventative and treatment interventions available for preventing childhood mortality (including antenatal checkups, delivery by trained personnel and DPT3 vaccinations) became ubiquitous, the number of under-five deaths worldwide might fall by as much as 63 percent. And one recent cross-country analysis suggests that, in countries with good governance, additional health spending and aid financing can have an impact on health outcomes (World Bank, 2003b). Yet this same study suggests how hard it would be to meet the health MDGs in Africa, and why the MDGs at their current levels are over-reaching. First, the average quality of African government institutions as measured by the World Bank's Country Policy and Institutional Assessment would have to leapfrog to one standard deviation above the mean global score (from significantly below the average today). Then government health expenditures as a percentage of GDP would have to reach as much as 16.5 percent - or an implausible level greater than that spent by any country in the world.

It may be that progress in meeting some of the other MDGs-perhaps in particular halting the spread of HIV/AIDS, reversing the incidence of malaria and halving the proportion of people without sustainable access to drinking water and sanitation—could in fact be rapid enough to meet the MDG timetable. ${ }^{33}$ This appears possible because a small number of technological advances, or a significant increase in investment in a particular infrastructure, could have a major effect on these areas in ways not obvious in the other goals. The creation of a malaria vaccine, for example, would have a 
monumental impact toward meeting the sixth $\mathrm{MDG},{ }^{34}$ but it is difficult to imagine a similar single technological advance that would significantly impact education outcomes. Additionally, donor funds have in the past played a valuable catalytic role in supporting research and development and in meeting supply-side shortages in these areas.

\section{Making the perfect the enemy of the good}

Growing concern that the MDGs will not be achieved should not obscure the bigger picture: development progress in terms of social indicators has been occurring at unprecedented levels throughout the great majority of the world's population over the past thirty or more years. For example, divergence in life expectancies between rich and poor countries that had been occurring since perhaps as early as the fifteenth century has been dramatically reversed in the second half of the last century. Between 1950-99 (using country-level data covering $87 \%$ of the world's population) the population weighted average life expectancy has risen from 51 to 69 years while the population-weighted standard deviation has fallen from 13 to 7 years (Kenny 2005). Data on infant survival suggests a similar performance. In the second half of the $20^{\text {th }}$ century, average global literacy increased from 52\% to $81 \%$, while the weighted standard deviation dropped from $38 \%$ to $17 \%$. Turning to female literacy as a percentage of male literacy, over the 1970 2000 period, the global average ratio has improved from 59\% to $80 \%$.

This reflects a dramatic long-term improvement in social indicators even for countries that have seen limited economic growth. For example, average life expectancy for countries at $\$ 300$ GDP per capita in 1999 is slightly higher than that for countries with a 
GDP per capita of $\$ 3,000$ in 1870 (in constant dollars). In other words, it now takes only one tenth the income to achieve the same life expectancy as it did 130 years ago (Kenny 2005).

It is hard to view this progress as anything other than a dramatic success. Even if divergence continues "big time" with regard to income (Pritchett 1997), other quality of life indicators suggest historically unprecedented improvement. There are, of course, significant clouds on the horizon - the AIDS pandemic is having a particularly dramatic impact in Sub-Saharan Africa, where life expectancy in the region as a whole has declined in recent years, and is likely to level off only in 2010 (Easterlin 2000). Nonetheless, it is not clear why we should expect progress to halt more broadly.

A continuation of the progress that has characterized the typical developing country of the last fifty years will, by and large, leave countries missing the MDGs in 2015, yet still outperforming the historical trajectories of now-developed countries. In Figure 8, for example, we see the trajectory of primary school enrollment for Burkina Faso. The country is on a trend well above the typical country since 1960 and even further ahead of the typical rich-country transition in the $19^{\text {th }}$ Century. (The same statement is true of Mali, Senegal, Madagascar, and Nicaragua, among others.) Surely this is not unambitious performance. Despite this success, Burkina Faso will fail to meet the MDG target. It is perhaps worth asking whether the success or the target should be questioned.

\section{Moving Forward: Re-interpreting the MDGs}


There is a long history of international goal setting for development. A steady succession of international conferences since the 1940s have for instance declared universal primary education achievable within a short-time period and pledged to make the necessary investments to do so (Clemens 2004). Nevertheless, countries all over the world continued to undergo the slow adjustments of their societies and economies that have allowed more children to go to school. But in setting unrealistic goals and claiming that they can in fact be universally met, the MDGs may run the risk of creating a climate of inaccurate pessimism about both development and aid.

The Millennium Development Goals can be understood in two ways. One interpretation is to take the specific goals of the MDGs literally—accepting them as the real targets of the development community —and take the costing study estimates as the amount of aid needed to reach those goals. This view sees the MDGs as an important mechanism for raising aid flows and ensuring accountability for donor promises. It also believes that a big push on aid—for example, the calling for a "Marshall Plan" for Africa—can accelerate progress beyond historical norms and meet the MDGs. A literal interpretation of the MDGs and a misreading of the costing studies can lead to the belief that huge aid flows can quickly produce epochal change in an array of development indicators across broad regions. Perhaps such outcomes will be achieved, particularly regarding the goals in areas such as water and sanitation, but as we have seen, the historical evidence suggests it is unlikely that the majority of goals will be reached by the majority of countries. 
The determinants of the outcomes embodied by the MDGs are in fact complex. Time itself clearly is an important factor, but this is not accounted for by universal time-bound goals. Many of the available interventions in terms of policy reforms or increases in resources are supply-side responses, and can do little to increase demand, which is linked to longer-term social and economic changes. Lack of demand is partly responsible for the low levels of education, health care, and other development indicators. This does not mean that poor people do not desire better standards of living; it does mean that the range of incentives faced by many poor people lead them to make choices that might contradict the outcomes represented in the MDGs. This offers one reason why outcomes seem to change only slowly, and also suggests that there may be a limited potential role for aid in meeting extremely ambitious, universal, time-bound goals. This does not claim in any sense that aid is unimportant or ineffective, but only that aid cannot by itself deliver the MDGs.

A second understanding of the MDGs is a more nuanced view-that the goals are a symbol of the kinds of outcomes toward which the development community should strive. Similarly, new aid flows are considered just one of several necessary conditions for progress on development indicators. By themselves, new aid flows are insufficient. We might imagine a pair of structural equations representing the relationship between aid and outcomes: The first of the two equations has progress towards the MDGs (such as school enrollments) on the left-hand side and aid on the right hand side, but there are many right-hand side variables, many of which interact with the effect of aid. The other equation has progress toward the MDGs on the right-hand side and aid on the left-hand 
side. ${ }^{37}$ For example, unit costs might give us some very rough idea of how much it would cost to pay for the schooling of all children in Mali if all of them were in school, but that number is the coefficient on schooling in the second equation, in which schooling causes aid. That coefficient need not provide any information about the coefficient on aid in the first equation. That is, such a number is potentially irrelevant to the "cost" of causing outcomes with aid.

This second interpretation takes the MDGs as a tool, not a practical target. Goals generate discussion, focus attention, and help assign accountability for leaders' pledges. The MDGs may have served these purposes to some degree. There can be little doubt that the MDGs helped galvanize the aid community and reverse the aid declines after the end of the Cold War. The United States, the European Union, Canada, Norway and others made promises of substantial aid increases at Monterrey in 2002, a result doubtlessly influenced by the MDG negotiations two years earlier.

In spite of these notable benefits of the MDGs—even when taken as symbolic rather than literal — there has been almost no discussion so far of potential costs of the specific form taken by these goals. These potential costs take two distinct forms: unreasonable expectations about what is likely to be achieved within a short time period, and unreasonable expectations about the role of aid in the development process.

First, the specific targets of the MDGs have set up many countries for unavoidable 'failure'. Some governments pursuing wise policies and making historically encouraging 
progress on development indicators could be weakened or delegitimized by the label of 'failure' in 2015. Many countries have made and will continue to make progress on the indicators comprised by the MDGs at historically extraordinary rates. The MDGs confuse interpretation of their performance with universal, time-bound targets that for many countries are, in practice, impossible to reach. Costing studies, by positing that such goals are attainable and asking merely for the resource inputs, contribute to the illusion that the goals are attainable for all countries. Even if most development practitioners know this is not true, they must recognize that the expectations of many have been raised.

Another potential downside is the possibility for adding to donor fatigue and distracting recipient countries from much-needed domestic reforms. If donors do provide additional tens of billions of dollars in aid per year sometime in the next few years, and if subsequently many of the goals are still not met, this will provide ammunition to interest groups in rich countries seeking to give up on development assistance. Developing countries will undoubtedly need many decades of sustained assistance-like Korea, Botswana, and other eventual successes received—and this must not be interrupted by declarations of failure in 2015. On the other hand, if the extra money does not materialize soon and the goals are not met in 2015, this may help legitimize several leaders in the developing world who pursue policies that are anathema to economic growth. What could we do, they will ask, when the rich countries broke their promises? The ensuing finger pointing could also undermine constituencies throughout the developing world for necessarily slow but essential reforms toward transparency, accountability, rule of law, and meritocracy. 
What to do now? Moving forward, the donor community should accept it is not feasible for the majority of countries to reach the majority of the MDGs. Similarly, the costing studies should not be invoked as evidence that we can purchase outcomes with more assistance. The studies themselves make no such claims, and history shows this is highly unlikely to be true. Instead, the MDGs should be presented as useful benchmarks that publicly bring out the stark contrast between the world we want and the world we have, and cause us to redouble our search for points of intervention to close the gap.

Second, the donor community might consider ways of institutionalizing the recognition of development success. The government of Burkina Faso, for example, should be supported and lauded by the international community for raising school enrollments much faster than most poor and now-rich countries did in the past, not criticized and delegitimized because primary enrollment is less than $50 \%$. Country-specific benchmarks can help signal when interventions of some kind are necessary, and they can also provide markers for progress along the way, given a country's circumstances. Much public discussion of the MDGs has instead revolved around compiling lists of "off-track" countries. A more constructive and useful approach might instead list countries that are 'on-track' or better after taking account of their particular circumstances and historical trends. Some kind of institutionalized response by the international community would thus redefine Burkina Faso as the educational success it has been. This would not in any way endorse the fact that half of Burkinabe children still do not enroll in school, nor imply in any way that schooling is not their right. It would, however, give important 
international pressure to support those who for decades have been working to get Burkinabe children into school at a rate faster than many far richer countries have managed.

Lastly, future international development goals might avoid some of these pitfalls. The next round of goals should: (a) be country-specific and flexible, more like today's IDA targets; (b) take historical performance into account; (c) focus more on intermediate targets than outcomes; (d) be considered benchmarks to spur action in cases where assistance is not working, rather than technically feasible goals.

This last point is worth emphasizing: It is useful to know that a country is raising school enrollments more slowly than the historically typical rate. It can give political support to constituencies in that country seeking changes in national policies, it can spur donors to intervene and support change through financial and other means. But this is much different from the effects of declaring that it is feasible for a country to raise enrollments at five times historically typical rates. Country-specific benchmarks carry the benefits of goal setting without the potential downsides of universal goals. This suggests that goal setting at the global level should be bottom-up rather than top-down-that is, the world targets should start from country goals and then aggregate up, rather than setting global goals and then estimating what countries would need to do to achieve them.

Indeed, for the next round of goals, the donor community might consider avoiding global-level costing studies, especially for outcomes known to be only tenuously linked 
to financial inputs. Rough back-of the-envelope estimates can potentially be useful for identifying the hypothetical scale of resources and also for some limited supply-side interventions. Yet the widespread misinterpretation of the studies suggests that, however narrowly conceived by the authors, that misuse appears difficult to avoid. A more direct approach might be to cost specific interventions and link them to intermediate indicators rather than outcomes-for example, costing an immunization program rather than child mortality. Calculating financing gaps and unit costs for final outcomes appear to merely create more illusion than illumination.

It is worth stressing the caveats attached to our analysis. None of this is to argue against aid or that goal setting is per se counterproductive. Aid has clearly been an important part of developmental progress for many countries. Perhaps aid levels should increase by $\$ 50$ billion, but not with the expectation that this will cause the MDGs to be met. Similarly, goals should indeed be set to enhance accountability and allocational efficiency, but goals must take history and context into account or potentially risk malign irrelevance.

Perhaps most significantly, we have based most of our argument on historical precedent. History can be a fickle guide to the future. To take two recent development trends as an example, the spread of the Internet has been more rapid than the spread of the mobile phone, which was in turn more rapid than the television, in turn more rapid than the fixed telephone. And the spread of democratic institutions in developing countries over the past fifteen years would have been poorly predicted based on a trend of declining democratic freedoms over the thirty years previously. It may be (and we hope it is) the case that 
policies will improve, that the environment for the effective utilization of aid becomes friendlier, and that technology and policy trends combine to allow historically unprecedented levels of progress across the broad range of development that is encompassed by the MDGs. Even if that is not the case, many countries will reach at least some of the MDG targets. More importantly, it is quite probable that the significant rate of improvement that we are already seeing in developing countries will continue in the next fifteen years, enhancing the lives of billions worldwide. 


\section{References}

AbouZahr, Carla and Tessa Wardlaw. 2001. "Maternal mortality at the end of a decade: signs of progress?” Bulletin of the World Health Organisation 79 (6): 561-573.

Action Aid. 2002. "Halfway there? The G8 and the Millennium Development Goals in 2002."

African Development Bank. 2002. Achieving the Millennium Development Goals in Africa: Progress, Prospects and Policy Implications. Global Poverty Report, June.

Besley, Tim and Robin Burgess. 2003. "Halving Global Poverty.” Journal of Economic Perspectives 17 (3):3-22.

Bhalla, Surjit. 2002. Imagine There's No Country: Poverty, Inequality, and Growth in the Era of Globalization, Washington DC: International Institute of Economics.

Brossard, Mathieu and Luc-Charles Gacougnolle. 2001. Financing Primary Education for All: Yesterday, Today and Tomorrow. Paris: UNESCO.

Bruns, Barbara, Alain Mingat, and Ramahatra Rakotomalala. 2003. Achieving universal primary education by 2015: A chance for every child. Washington DC: World Bank.

Burnside, Craig and Dollar, David. 2000. “Aid, Policies, and Growth.” American Economic Review. 90 (4): 847-68.

Carceles, Gabriel, Birger Fredriksen, and Patrick Watt. 2001. "Can Sub-Saharan Africa Reach the International Targets for Human Development?” Africa Region Human Development Working Paper Series. Washington DC: World Bank.

Cassen, Robert. 1994. Does Aid Work? Oxford: Oxford University Press.

Clemens, Michael. 2004. "The Long Walk to School: International education goals in historical perspective.” Working Paper 37. Washington, DC: Center for Global Development.

Clemens, Michael, Steven Radelet and Rikhil Bhavnani. 2004), "Counting chickens when they hatch: The short-term effect of aid on growth." Working Paper 44. Washington, DC: Center for Global Development.

Collier, Paul and David Dollar. 2000. "Can the World Cut Poverty in Half? How Poverty Reform and Effective Aid Can Meet International Development Goals.” Policy Research Working Paper 2403. Development Research Group. Washington DC: World Bank.

Dalgaard, C-J.,H. Hansen, F. Tarp. 2004. “On The Empirics of Foreign Aid and Growth.” The Economic Journal 114: 191-216.

Delamonica, Enrique, Santosh Mehrotra, and Jan Vandemoortele. 2001. "Is EFA Affordable? Estimating the Global Minimum Cost of 'Education for All'.” Innocenti Working Paper 87. UNICEF. 
Devarajan, Shantayanan, Margaret J. Miller, and Eric V. Swanson. 2002. "Goals for Development: History, Prospects and Costs.” Policy Research Working Paper 2819, Washington DC: World Bank.

Devarajan, Shantayanan, William R. Easterly, and Howard Pack. 2002. "Low Investment is not the Constraint on African Development.” Working Paper No. 13, Center for Global Development, Washington DC, October.

Dollar, David and Aart Kraay. 2001. “Growth is Good for the Poor.” World Bank Policy Research Working Paper 2587, Washington DC.

Easterlin, Richard. 2000. “The Worldwide Standard of Living since 1800, Journal of Economic Perspectives 14 (1): 7-26.

Easterly, William. 1999. "The Ghost of Financing Gap: Testing the Growth Model Used in the International Financial Institutions.” Journal of Development Economics 60 (2): 423-438.

Easterly, William. 2001. The Elusive Quest for Growth. Cambridge, MA: MIT Press.

Easterly, William. 2003a. “Can foreign aid buy growth?” Journal of Economic Perspectives 17 (3): 23-48.

Easterly, William. 2003b. "National Policies and Economic Growth: A Reappraisal.” Working Paper No. 27. Washington, DC: Center for Global Development.

Easterly, William, Michael Kremer, Lant Pritchett, and Lawrence Summers. 1993. "Good Policy or Good Luck? Country Growth Performance and Temporary Shocks.” Journal of Monetary Economics 32 (3): 459-483.

Easterly, William, Ross Levine, and David Roodman. 2003. "New Data, New Doubts: Revisiting ‘Aid, Policies and Growth'”’ Working Paper 26. Washington DC: Center for Global Development.

Fay, Marianne and Tito Yepes. 2003. "Investing in Infrastructure: What is Needed from 2000 to 2010?” Policy Research Working Paper 3102. Washington, DC: World Bank.

Filmer, Deon. 2002. “Costing the Goal of Universal Primary Enrollments by 2015: Back of the (Big) Envelope Calculations.” Washington, DC: World Bank.

Filmer, Deon. 2004. "School availability and school participation in 21 developing countries.” Mimeo. Washington, DC: World Bank.

Filmer, Deon, Jeffrey Hammer and Lant Pritchett. 2000. "Weak Links in the Chain: A Diagnosis of Health Policy in Poor Countries.” World Bank Research Observer 15 (2): 199-224.

Gottschalk, Ricardo. 2000. "Growth and Poverty Reduction in Developing Countries: How Much External Financing Will Be Needed in the New Century?” Institute of Development Studies, University of Sussex.

Greenhill, Romilly. 2002. "The unbreakable link—debt relief and the millennium development goals.” Report from Jubilee Research at the New Economics Foundation.

Guillamont, P. and L. Chauvet. 2001. “Aid and Performance: A Reassessment.” Journal of Development Studies 37 (6): 66-92. 
Hanmer, L. and H. White. 1999. "Human Development in Sub-Saharan Africa: The Determinants of Under-Five Mortality.” Mimeo. The Hague: Institute of Social Studies Advisory Service.

Hanmer, L., R. Lensink and H. White. 2003. "Infant and Child Mortality in Developing Countries: Analysing the Data for Robust Determinants.” Journal of Development Studies 40 (1): 101-118.

Hansen, H. and F. Tarp. 2001. “Aid and Growth Regressions.” Journal of Development Economics 64 (2): 547-570.

Heller, Peter and Sanjeev Gupta. 2002. “Challenges in Expanding Development Assistance.” Policy Discussion Paper, PDP/02/05. Washington, DC: International Monetary Fund.

Hicks, Norman. 1982. "Sector Priorities in Meeting Basic Needs: Some Statistical Evidence.” World Development 10 (6): 489-499.

Kenny, Charles. 1999. “Why Aren’t Countries Rich? Weak States and Bad Neighborhoods.” Journal of Development Studies 35 (5): 26-47.

Kenny, Charles. 2005. "Why Are We Worried About Income? Everything that Matters is Converging." World Development forthcoming.

Kenny, Charles and David Williams. 2001. "What Do We Know About Economic Growth? Or, Why Don’t We Know Very Much?” World Development 29 (1): 122.

Kraay, Aart. 2004. "When is Growth Pro-Poor? Cross Country Evidence." Policy Research Working Paper 3225. Washington DC: World Bank.

Kremer, Michael and Edward Miguel. 2001. "Worms: Education and Health Externalities in Kenya.” Working Paper No. 8481. Cambridge, MA: National Bureau of Economic Research.

Leipziger, D, M. Fay, Q. Wodon and T. Yepes. 2003. “Achieving the Millennium Development Goals: The Role of Infrastructure.” Policy Research Working Paper 3163. Washington, DC: World Bank.

Lensink, R. and H. White. 2001. “Are there Negative Returns to Aid?” Journal of Development Studies,. 37 (6): 42-65.

Marcelo, Ray. 2003. “India Opts to Decline Aid from All but Six Countries.” Financial Times, July 8.

McCarthy, F. Desmond, H. Wolf and Y. Wu. 2000. "The Growth Costs of Malaria.” Working Paper 7541. Cambridge, MA: National Bureau of Economic Research.

Mills, Anne and Sam Shillcutt. 2004. "Copenhagen Consensus Challenge Paper on Communicable Diseases.” Copenhagen Consensus Challenge Paper.

Mingat, Alain, Ramahatra Rakotomalala, and Jee-Peng Tan. 2002. "Financing Education for All by 2015: Simulations for 33 African Countries.” Africa Region. Washington, DC: World Bank.

Mosley, P., J. Hudson, A. Verschoor. 2004) Aid, Poverty Reduction and the 'New Conditionality’ Economic Journal 114: 217-243. 
Naschold, Felix. 2002. "Aid and the Millennium Development Goals." ODI Opinions, February.

Overseas Development Institute. 2003. "Can We Attain the Millennium Development Goals in Education and Health Through Public Expenditure and Aid?” Briefing Paper. London: Overseas Development Institute.

Oxfam. 2002. "Last Chance at Monterrey: Meeting the challenge of poverty reduction.” Briefing Paper No. 17. Oxford: Oxfam.

Pritchett, Lant. 1994. "Desired Fertility and the Impact of Population Policies." Population and Development Review 20 (1): 1-55.

Pritchett, Lant. 1997. “Divergence, Big Time.” Journal of Economic Perspectives 11 (3) 3-17.

Pritchett, Lant. 2004. "Towards a New Consensus for Addressing the Global Challenge of the Lack of Education.” Copenhagen Consensus Challenge Paper.

Pritchett, Lant and Lawrence H. Summers. 1996. "Wealthier is Healthier.” Journal of Human Resources 31 (4): 841-868.

Ranis, G. and F. Stewart. 2001. "Growth and Human Development: Comparative Latin American experience.” Developing Economies 39: 333-365.

Sachs, Jeffrey. 1996. “Growth in Africa: It Can be Done.” The Economist, June 29.

Sachs, Jeffrey. 1997. "The Limits of Convergence.” The Economist, June 14.

Sahn, David E. and David C. Stifel. 2003. "Progress Toward the Millennium Development Goals in Africa.” World Development 31 (1): 23-52.

Schiffman, J. 2000. “Can Poor Countries Surmount High Maternal Mortality?” Studies in Family Planning 31 (4): 274-289.

Thorbecke, Erik and Chutatong Charumilind. 2002. "Economic Inequality and Its SocioEconomic Impact.” World Development 30 (9): 1477-1495.

Toulmin, Camilla and Bara Gueye. 2003. "How will West African Countries meet the MDGs?” In David Satterthwaite, ed. The Millennium Development Goals and Local Processes: Hitting the target or missing the point? London: International Institute for Environment and Development.

UNESCO. 1966), An Asian model of educational development: Perspectives for 1965-80. Paris: UNESCO.

United Nations. 2002. "Report of the International Conference on Financing for Development.” Monterrey, Mexico, 18-22 March, A/CONF.198/11.

United Nations Development Program. 2002. Financing the Development Goals: An analysis of Tanzania, Cameroon, Malawi, Uganda and Philippines. Summary Report, March.

United Nations Development Program. 2003. Human Development Report, Geneva.

Vandemoortele, Jan. 2002. “Are the MDGs Feasible?” New York: UNDP Bureau for Development Policy.

White, Howard. 2002. "Using the Millennium Development Goals as a Basis for AgencyLevel Performance Measurement.” Sussex: Institute of Development Studies. 
World Bank. 2002. "Education for Dynamic Economies: Action Plan to Accelerate Progress Towards Education for All.” Prepared by the World Bank Staff for the Spring Development Committee Meeting, April.

World Bank. 2003a. Supporting Sound Policies with Adequate and Appropriate Financing: Implementing the Monterrey Consensus at the Country Level. Washington DC.

World Bank. 2003b. The Millennium Development Goals in Health: Rising to the Challenge. Washington DC.

World Bank. 2004a. Strategic Framework for Assistance to Africa: IDA and the Emerging Partnership Model. Africa Region. Washington DC.

World Bank. 2004b. World Development Report. Washington DC.

World Bank. 2004c. World Development Indicators. Washington DC. 
Table 1: Costing the MDGs: A Sample of studies

\begin{tabular}{|c|c|c|}
\hline Study & Covering & $\begin{array}{l}\text { Estimate of } \\
\text { additional } \\
\text { resources per year }\end{array}$ \\
\hline \multirow{3}{*}{$\begin{array}{l}\text { Devarajan, et al. "Goals for } \\
\text { Development" (World Bank, April } \\
\text { 2002) }\end{array}$} & Global poverty goal & $\$ 54-62$ billion \\
\hline & $\begin{array}{l}\text { Global social and environmental } \\
\text { goals }\end{array}$ & $\$ 35-75$ billion \\
\hline & Global primary education & $\$ 10-15$ billion \\
\hline $\begin{array}{l}\text { Vandemoortele, "Are the MDGs } \\
\text { feasible?" (UNDP, July 2002) }\end{array}$ & Global MDGs & $\$ 50-80$ billion \\
\hline \multirow[t]{2}{*}{$\begin{array}{l}\text { Greenhill, "The Unbreakable link" } \\
\text { (Jubilee Research 2002) }\end{array}$} & Global poverty goal & $\begin{array}{l}\$ 15-46 \text { billion, plus } \\
100 \% \text { debt } \\
\text { cancellation }\end{array}$ \\
\hline & Global, other goals & $\begin{array}{l}\$ 16.5 \text { billion, plus } \\
100 \% \text { debt } \\
\text { cancellation }\end{array}$ \\
\hline $\begin{array}{l}\text { "Last Chance in Monterrey" (Oxfam } \\
\text { 2002) }\end{array}$ & Global MDGs & $\$ 100$ billion \\
\hline \multirow{2}{*}{$\begin{array}{l}\text { "Supporting Sound Policies..." } \\
\text { (World Bank 2003a) }\end{array}$} & Asia and South Asia & double or triple aid \\
\hline & Africa and Central Asia & $60 \%$ increase \\
\hline $\begin{array}{l}\text { "Achieving the MDGs in Africa..." } \\
\text { (African Development Bank 2002) }\end{array}$ & Sample of 30 African countries & $\$ 20-25$ billion \\
\hline Delamonica et al. (Unicef 2001) & Global primary education & $\$ 9.1$ billion \\
\hline \multirow[t]{2}{*}{$\begin{array}{l}\text { "Education for Dynamic } \\
\text { Economies..." (World Bank 2002) }\end{array}$} & $\begin{array}{l}\text { Primary education for } 47 \text { IDA } \\
\text { countries "at risk" }\end{array}$ & $\$ 2.5-5$ billion \\
\hline & African primary education & $7 x$ aid \\
\hline $\begin{array}{l}\text { Naschold, "Aid and the MDGs" (ODI } \\
\text { 2002) }\end{array}$ & Global primary education & $\$ 9$ billion \\
\hline $\begin{array}{l}\text { Filmer, "Costing the Goal..." (World } \\
\text { Bank 2002) }\end{array}$ & Global Primary education & $\$ 30$ billion \\
\hline $\begin{array}{l}\text { Mingat, et al. "Financing Education } \\
\text { for all..." (World Bank 2002) }\end{array}$ & $\begin{array}{l}\text { Primary Education for } 33 \text { African } \\
\text { countries }\end{array}$ & $\$ 2.1$ billion \\
\hline $\begin{array}{l}\text { Brossard and Gacougnolle, } \\
\text { "Education Primaire Universelle: } \\
\text { Combien?" (Unesco 2001) }\end{array}$ & African primary education & $\$ 2.9-3.4$ billion \\
\hline $\begin{array}{l}\text { Bruns et al., A Chance for Every } \\
\text { Child (World Bank 2003) }\end{array}$ & Low-income primary education & $\$ 5-7$ billion \\
\hline
\end{tabular}

The thrid column is meant only to give an indication of the additional resource estimates from a sample of studies. These figures may not be directly comparable as some of the figures cited in this column are in constant US dollars with different base years, ranging from 1995 to 2002. Similarly, some studies distinguish between "total additional resources" and "external financing requirements" (netting out an estimate of increased domestic resources). Given the range of assumptions and deviations in estimates, we did not attempt to rectify these disparities for comparability. Our intention is merely to give a sense of the range of cost estimates that have been undertaken. 
Figure 1: Hope springs eternal: Various growth goals compared to growth performance.

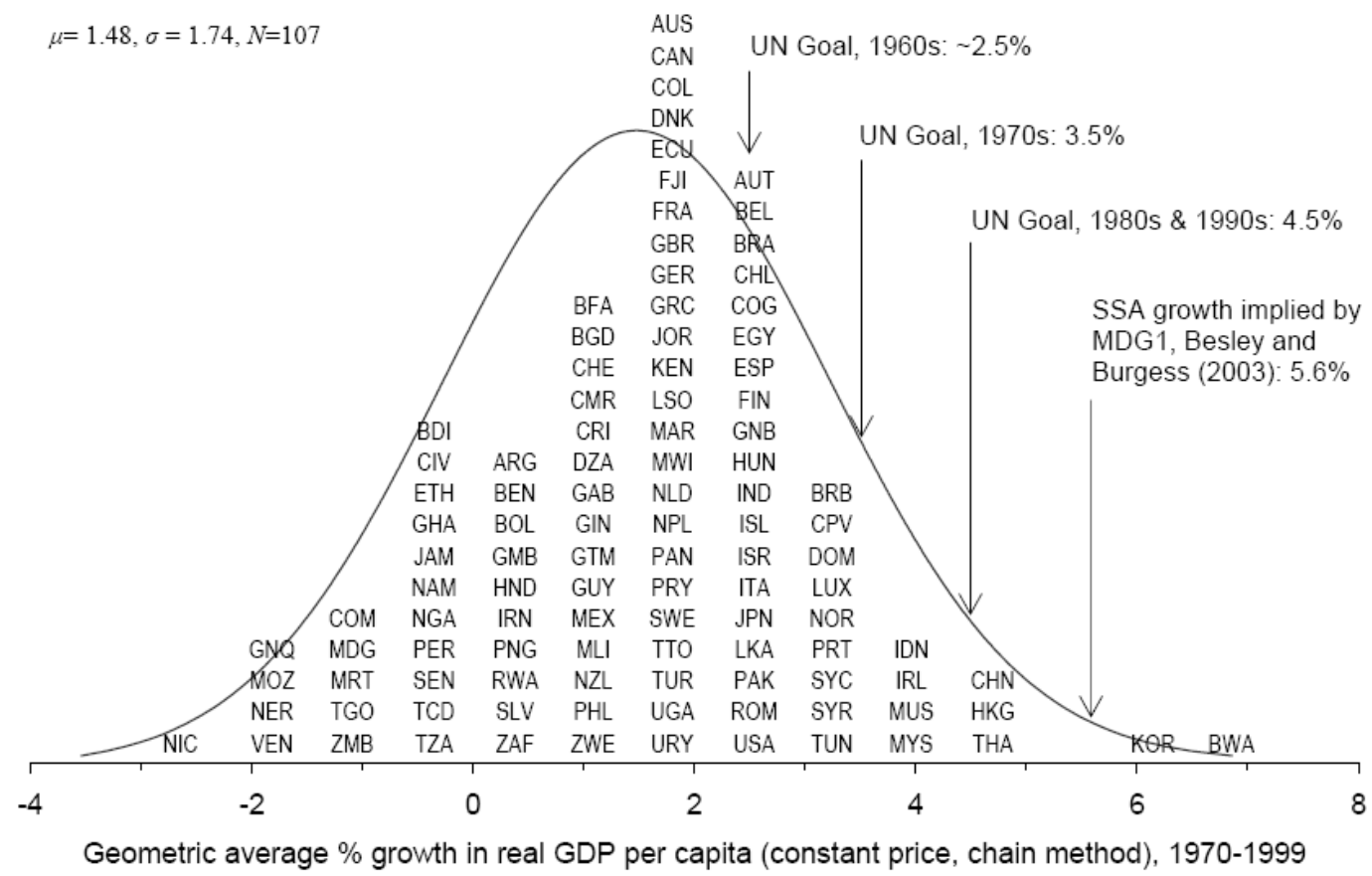


Figure 2: Uniformity in the increase of net primary enrollments, 1960-2000.

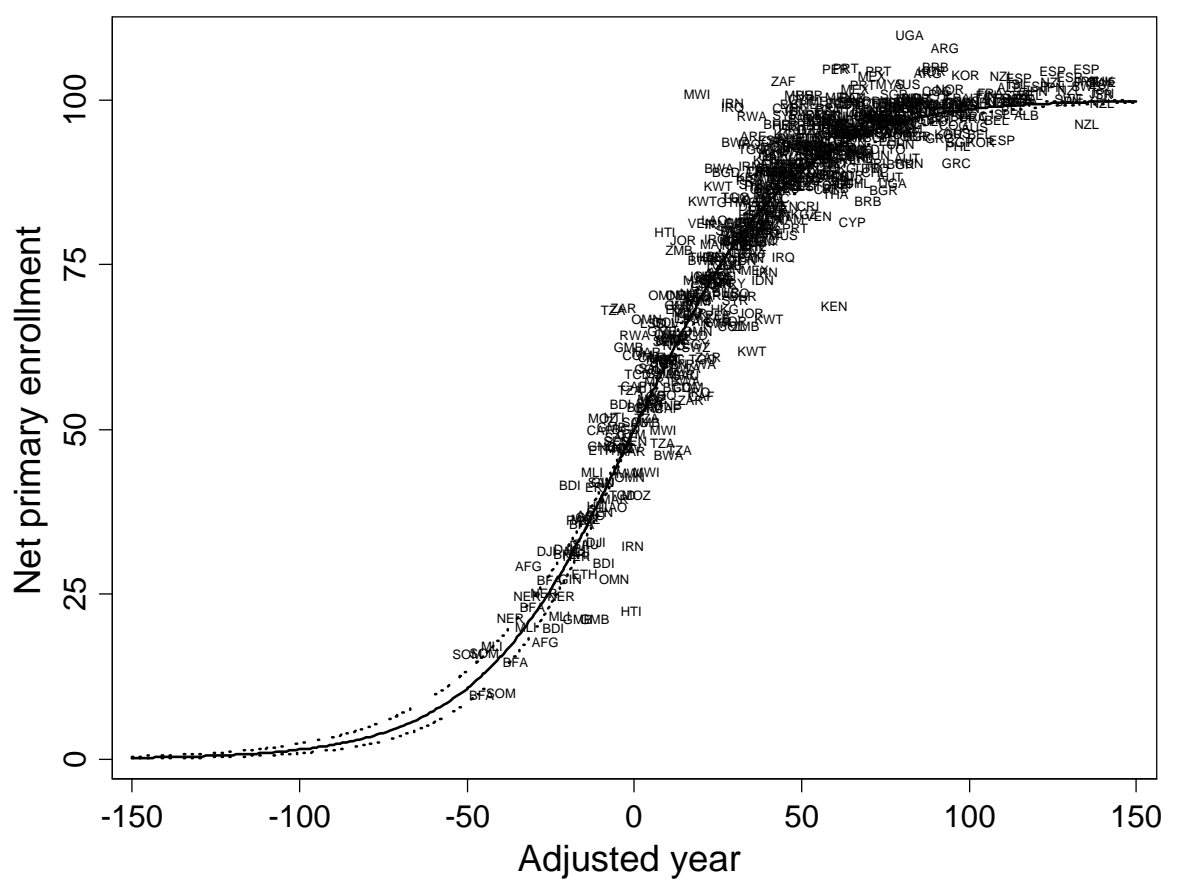

Source: Clemens (2004). 
Figure 3: What it would take to meet Goal Two.

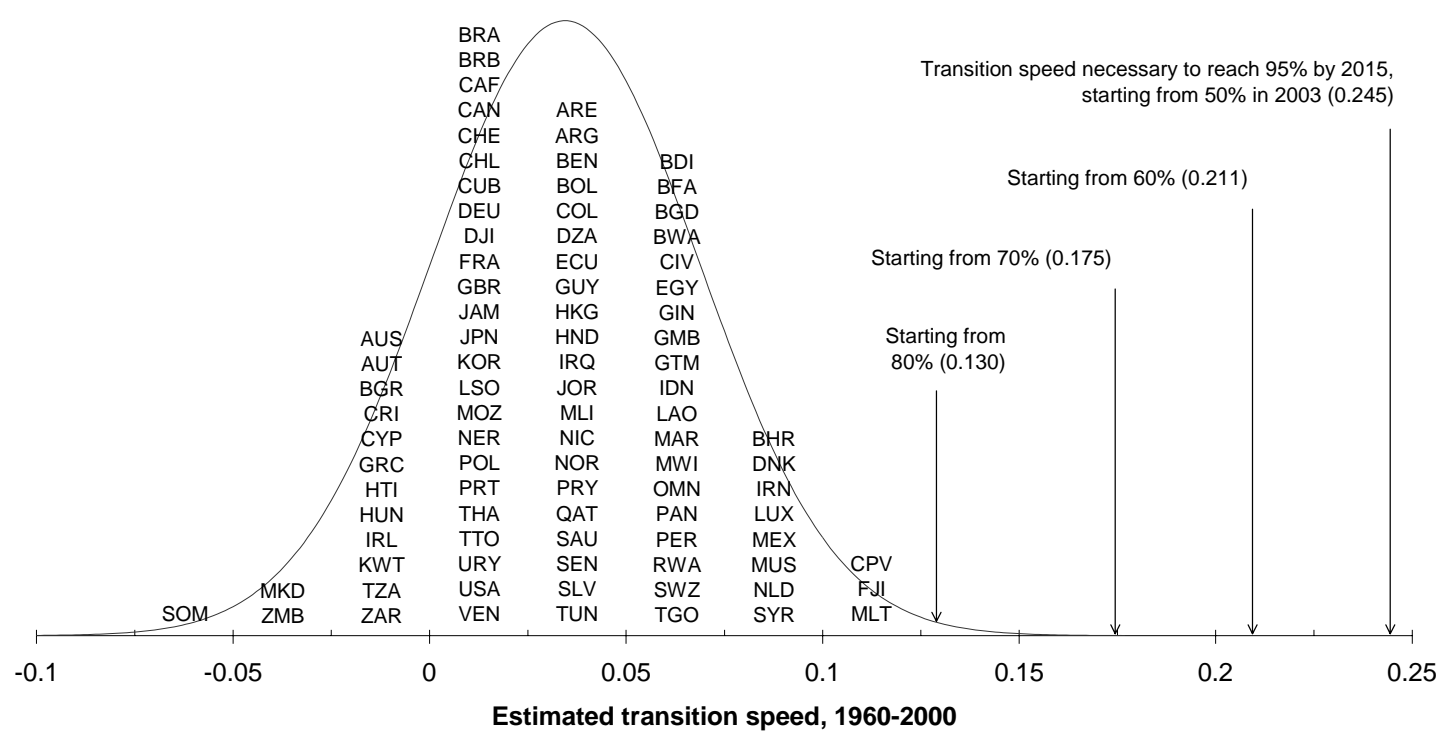

Source: Clemens (2004). 
Figure 4: Uniformity in the increase in female-to-male gross primary enrollment ratios, 1950-2000.

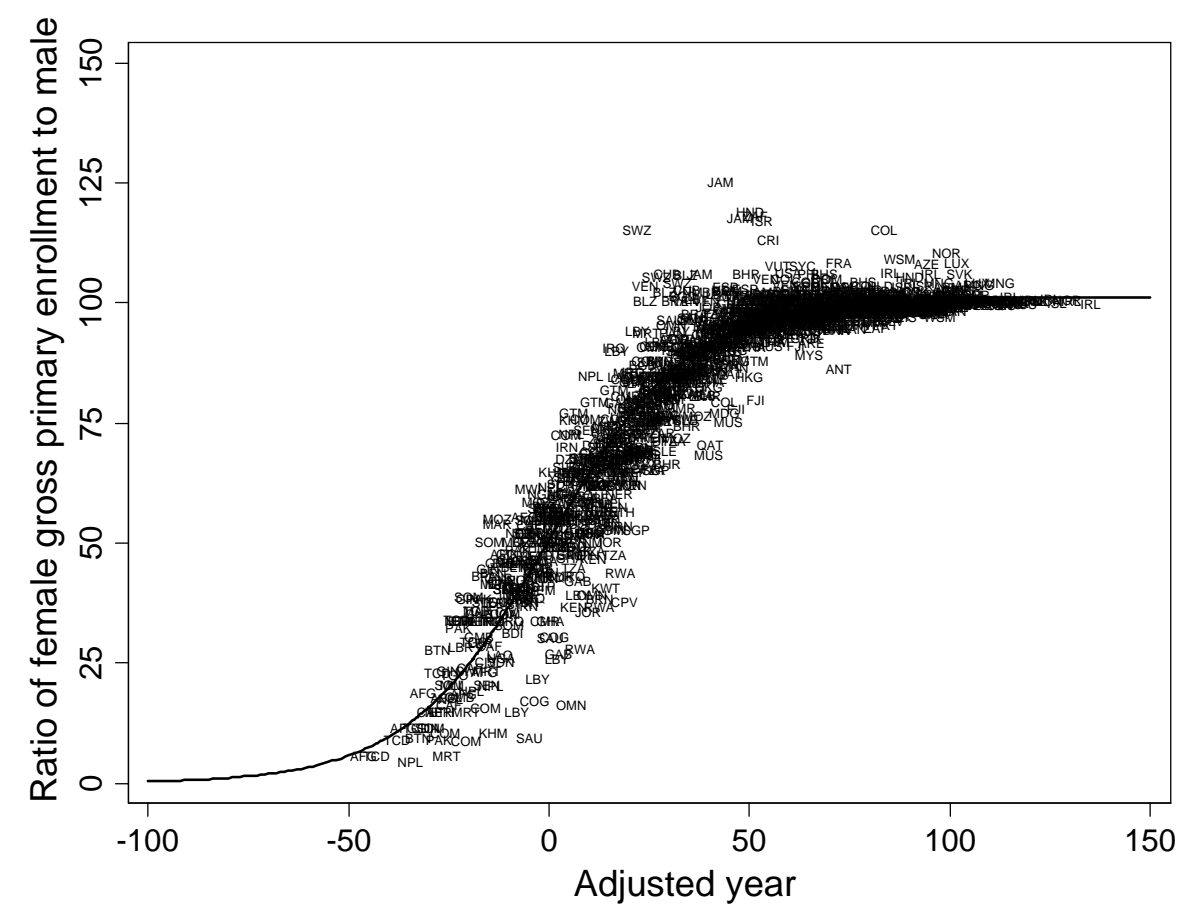

Source: Clemens (2004). 
Figure 5: The course of Infant mortality in 35 countries over roughly the $20^{\text {th }}$ century

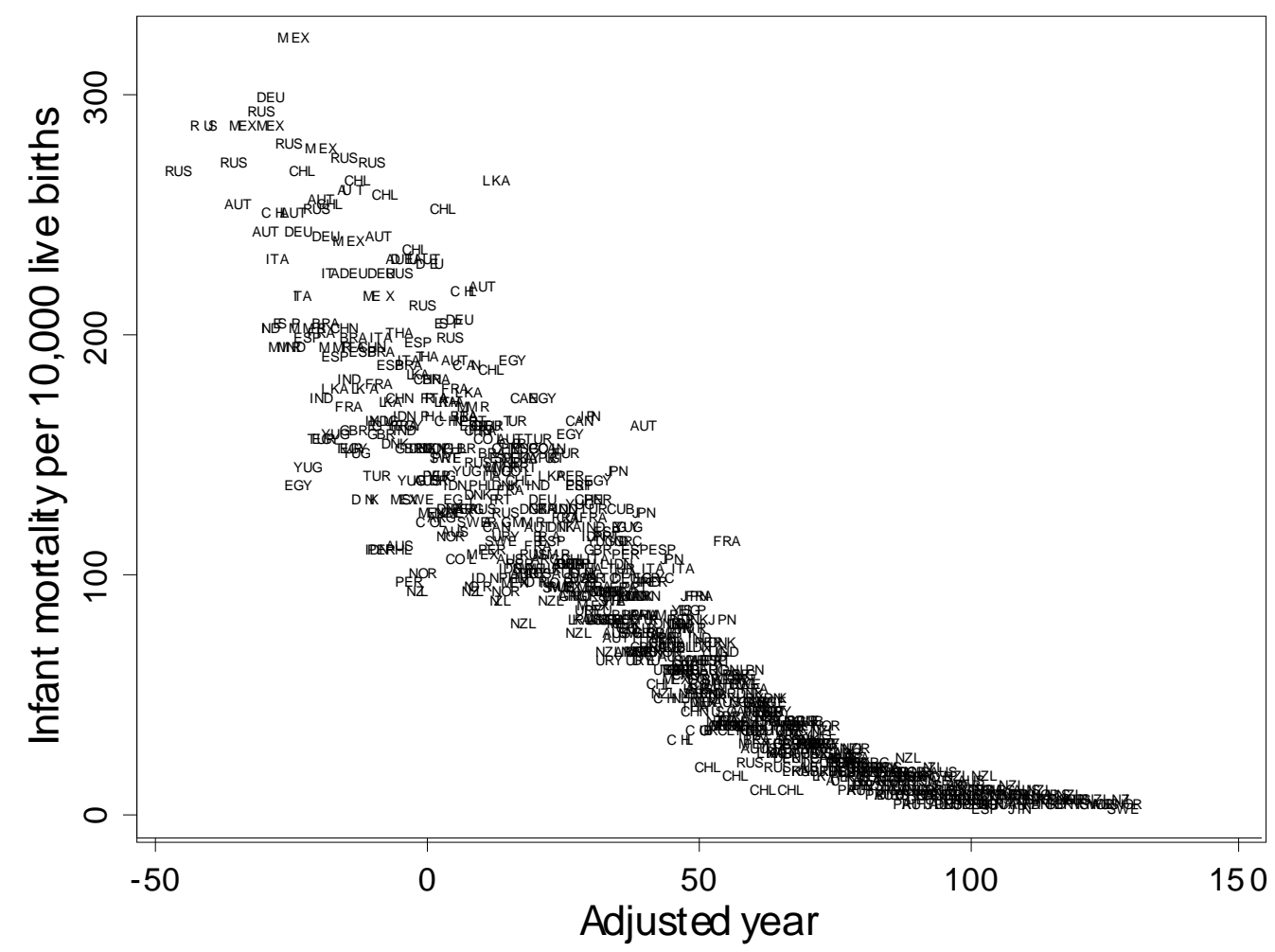

Infant mortality is deaths before age one per 10,000 live births. Data are quinquennial and aligned horizontally assuming that all pass through $50 \%$ of a maximum value of 350 in "adjusted year" zero For sources and country-by-country date ranges, see Data Appendix 
Figure 6: Despite major progress on child mortality, only one country with a GDP/Capita of below \$1,600 in 1975 would have reached MDG 4 had it been set in that year.

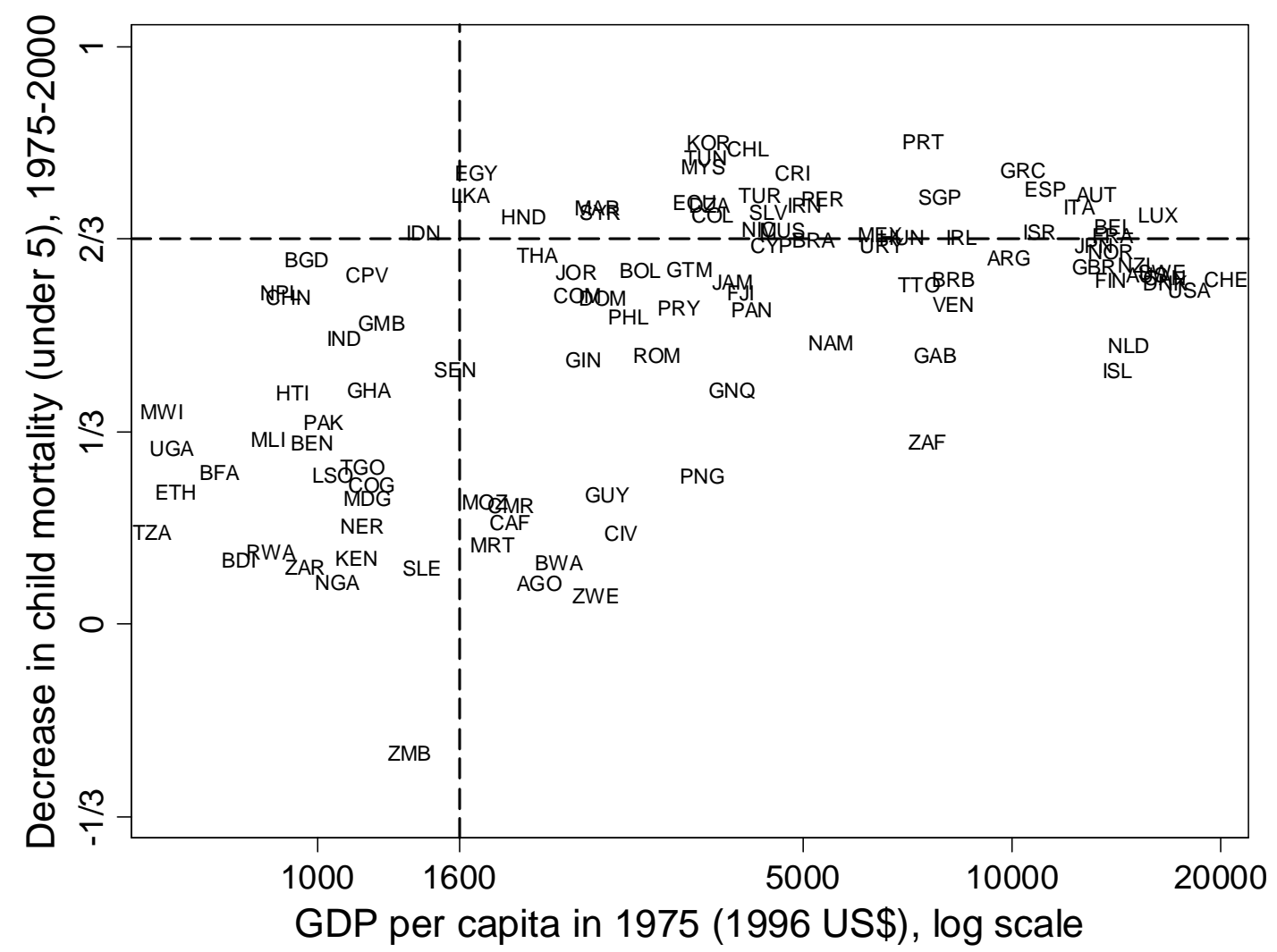

The decrease in child mortality is equal to one minus the ratio of child mortality in 2000 to child mortality in 1975 , where child mortality is the number of children dying before age 5 per 10,000 live births. Child mortality data are from the World Bank, World Development Indicators 2003. Real GDP per capita data are from the Penn World Tables 6.1. 
Figure 7: Seven out of 42 countries with incomes per capita below $\$ 1,600$ for which we have data were able to reduce maternal mortality during the 1990s at the annual rate required by Goal Five.

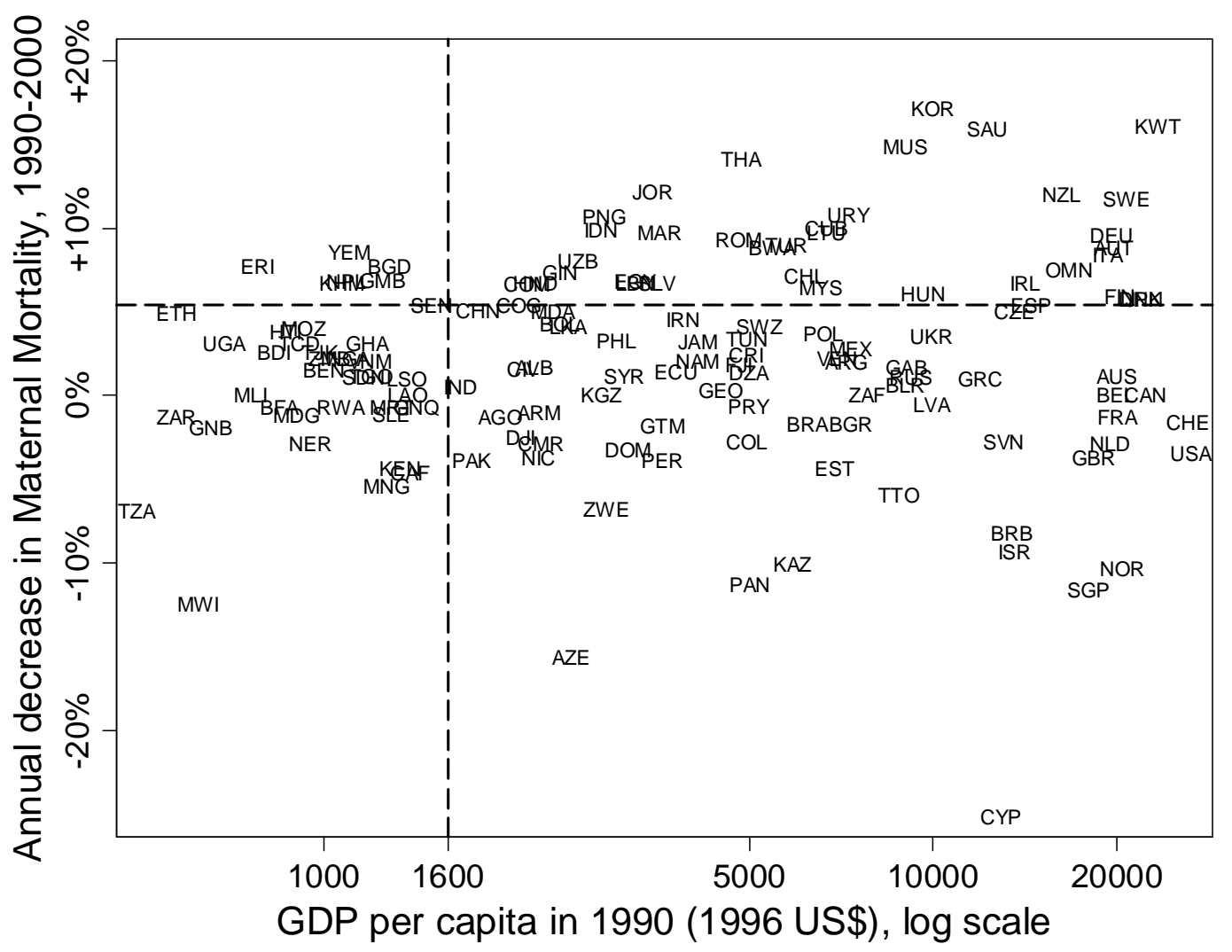

MDG 5, Target 6 is "Reduce by three quarters, between 1990 and 2015, the maternal mortality ratio". A cumulative decrease of $75 \%$ over 25 years implies an average annual decrease of 5.4\%, the rate marked with a horizontal line in the figure above. Sources: Year 1990 mortality from World Health Organization. Year 2000 mortality from WHO, UNICEF and UNFPA, Maternal Mortality in 2000. Real GDP per capita data are from the Penn World Tables 6.1. 
Figure 8: Many countries unlikely to meet the MDG for primary schooling are performing strongly by historical standards

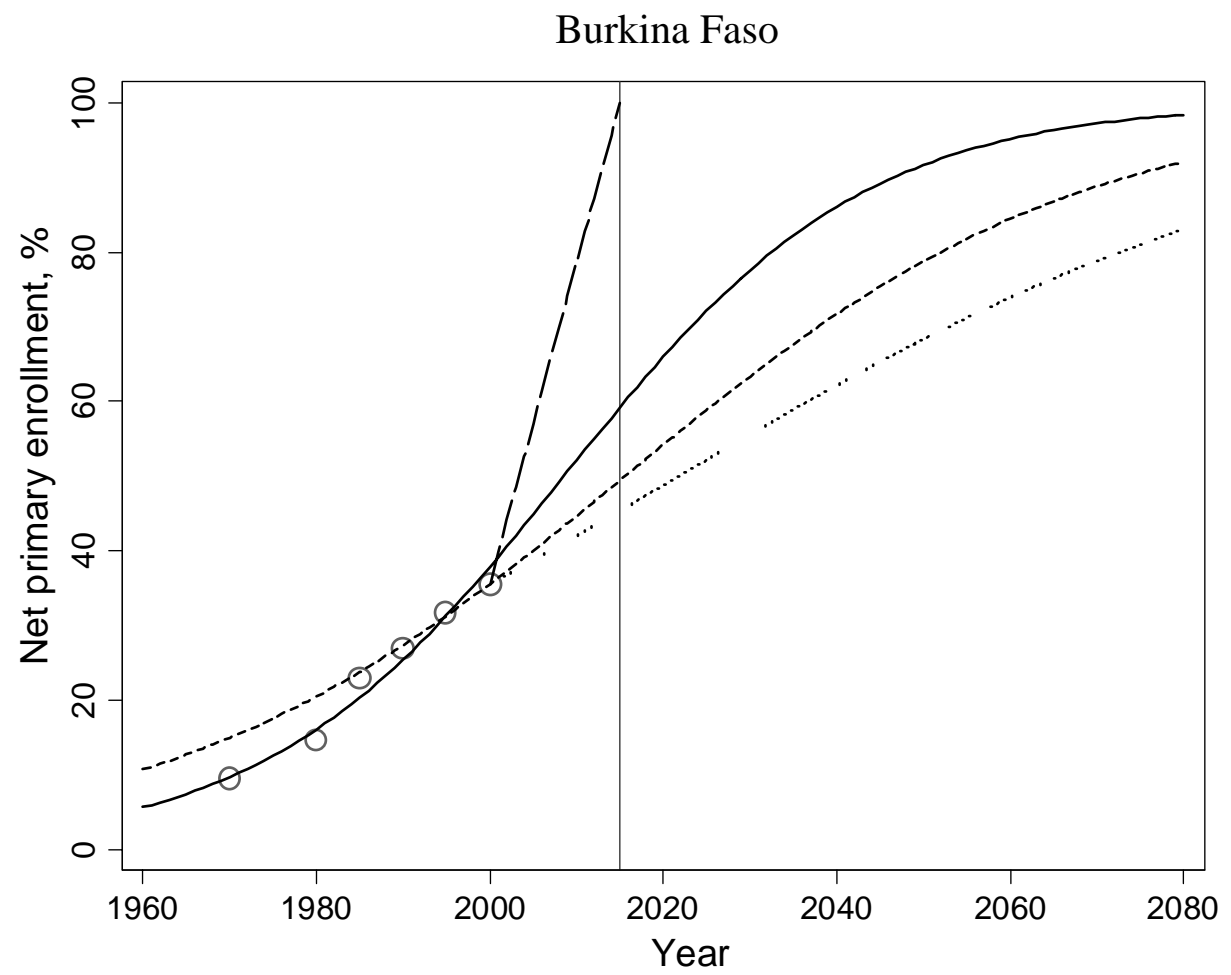

Source: Clemens (2004) 


\section{Appendix: Table A-1, The Eight Millennium Development Goals (and 18 targets)}

\begin{tabular}{|c|c|c|c|}
\hline Goal & & Target & \\
\hline 1. & $\begin{array}{l}\text { Eradicate extreme } \\
\text { poverty and hunger }\end{array}$ & $\bullet$ & $\begin{array}{l}\text { Halve, between } 1990 \text { and } 2015 \text {, the proportion of people } \\
\text { whose income is less than } \$ 1 \text { a day } \\
\text { Halve, between } 1990 \text { and } 2015 \text {, the proportion of people who } \\
\text { suffer from hunger }\end{array}$ \\
\hline 2. & $\begin{array}{l}\text { Achieve universal } \\
\text { primary education }\end{array}$ & $\bullet$ & $\begin{array}{l}\text { Ensure that, by 2015, children everywhere, boys and girls } \\
\text { alike, will be able to complete a full course of primary } \\
\text { schooling }\end{array}$ \\
\hline 3. & $\begin{array}{l}\text { Promote gender equality } \\
\text { and empower women }\end{array}$ & $\bullet$ & $\begin{array}{l}\text { Eliminate gender disparity in primary and secondary } \\
\text { education preferably by } 2005 \text { and in all levels of education } \\
\text { no later than } 2015\end{array}$ \\
\hline 4. & Reduce child mortality & $\bullet$ & $\begin{array}{l}\text { Reduce by two-thirds, between } 1990 \text { and 2015, the under- } \\
\text { five mortality rate }\end{array}$ \\
\hline 5. & Improve maternal health & $\bullet$ & $\begin{array}{l}\text { Reduce by three-quarters, between } 1990 \text { and 2015, the } \\
\text { maternal mortality ratio }\end{array}$ \\
\hline 6. & $\begin{array}{l}\text { Combat HIV/AIDS, } \\
\text { malaria, and other } \\
\text { diseases }\end{array}$ & & $\begin{array}{l}\text { Have halted by } 2015 \text { and begun to reverse the spread of } \\
\text { HIV/AIDS } \\
\text { Have halted by } 2015 \text { and begun to reverse the incidence of } \\
\text { malaria and other major diseases }\end{array}$ \\
\hline 7. & $\begin{array}{l}\text { Ensure environmental } \\
\text { sustainability }\end{array}$ & $\begin{array}{l}\bullet \\
\bullet \\
\bullet\end{array}$ & $\begin{array}{l}\text { Integrate the principles of sustainable development into } \\
\text { country policies and program and reverse the loss of } \\
\text { environmental resources } \\
\text { Halve, by 2015, the proportion of people without sustainable } \\
\text { access to safe drinking water and basic sanitation } \\
\text { Have achieved, by } 2020 \text {, a significant improvement in the } \\
\text { lives of at least } 100 \text { million slum dwellers }\end{array}$ \\
\hline 8. & $\begin{array}{l}\text { Develop a global } \\
\text { partnership for } \\
\text { development }\end{array}$ & $\bullet$ & $\begin{array}{l}\text { Seven targets related to: trade; special needs of poor } \\
\text { countries; special needs of landlocked countries and small } \\
\text { island developing states; debt problems of developing } \\
\text { countries; work for youth; affordable drugs; technology }\end{array}$ \\
\hline
\end{tabular}




\section{Appendix: Data sources}

Infant mortality 1870-2000: Taken from the appropriate edition of Mitchell's International Historical Statistics (1992, 1993, 1998) for 29 of the 35 countries. The six requiring alternate sources are Brazil, Burma, China, Indonesia, Thailand, and Turkey. For the period 1921-1938, figures for Burma, Thailand, and Turkey come from the League of Nations, Statistical Year-Book of the League of Nations (Geneva: League of Nations Economic Intelligence Service, 1941). In case of Thailand, the data refer to the "straits settlements" (which includes modern-day Thailand, Malaysia and Singapore) and after 1936 the Thai figures come from Constance M. Wilson, Thailand: A Handbook of Historical Statistics, (Boston: G.K. Hall \& Co., 1983), p. 46. For Turkey, the average of Greece, Yugoslavia and Egypt is used for benchmarks, and for the missing Turkish years in between those benchmarks, the trend for Egypt is assumed. Figures for Brazil are taken from A. K. Ludwig, Brazil: A Handbook of Historical Statistics (Boston: G.K. Hall \& Co., 1985), p. 84. The unweighted average of the infant mortality rates of urban counties is used to estimate Brazil's overall infant mortality rate. Infant mortality rates for Peru come from Mitchell (1993) from 1940 onwards. Before 1940, Peru is assumed to follow Colombia's trend. Figures for China are estimated by India's infant mortality rates, while the infant mortality rates of the Philippines are used as a proxy for Indonesia.

In Figure 5, infant mortality is deaths before age one per 10,000 live births. Data are quinquennial and aligned horizontally assuming that all pass through $50 \%$ of a maximum value of 350 in "adjusted year" zero. The countries are (with start year of data in parentheses if not 1870): Argentina (1915), Australia, Austria-Hungary (Austria), Brazil (1920), Burma (Myanmar) (1925-1935, 1960-2000), Canada (1900), Ceylon (Sri Lanka) (1905), Chile (1905), China (1915), Colombia (1925), Cuba (1935), Denmark, Egypt (1920), France, Germany, Greece (1925), India (1915, except 1950), Netherlands Indies (Indonesia) (1905), Italy, Japan (1920), Mexico (1900), New Zealand, Norway, Peru (1925), Philippines (1905), Portugal (1915), Russia (1870-1950, 1980-2000), Serbia (Yugoslavia) (1890), Spain, Sweden, Siam (Thailand) (1925-1935, 1960-2000), Anatolia (Turkey) (1925-1935, 1960-2000), United Kingdom, United States (1915), Uruguay (1925). 


\section{Notes}

JEL codes F35, O19, O2, O57. Michael Clemens (mclemens@cgdev.org) and Todd Moss (tmoss@cgdev.org) are Research Fellows at the Center for Global Development. Charles Kenny (ckenny@worldbank.org) is a Senior Economist at the World Bank. We thank Alicia Bannon and Scott Standley for excellent research assistance, and Colin Bradford, Bill Cline, Shanta Devarajan, Kim Elliott, Alan Gelb, Eveline Herfkens, Julie Kennedy, Maureen Lewis, John MacArthur, Steve Radelet, David Roodman, Markus Scheuermaier, Gayle Smith, Peter Timmer, Jeremy Weinstein, and John Williamson for helpful comments on an earlier draft. We also thank the many participants at presentations of the paper at the World Bank, the Executive Office of the Secretary General of the UN, and the Overseas Development Institute for their constructive comments. All judgments, opinions, and errors are those of the authors alone and do not represent the views of the Center for Global Development, the World Bank, or either of their respective staffs, boards of directors, or funders, nor the countries that the Executive Directors of the World Bank represent.

${ }^{1}$ UN General Assembly document A/RES/55/2, Sept. 8, 2000.

2 In December 2000, the UN General Assembly requested that Secretary General Kofi Annan prepare a "road map" of how to achieve the targets of the Millennium Declaration to which the leaders at the Millennium Summit had committed in September of that year (General Assembly resolution $\mathrm{A} / \mathrm{RES} / 55 / 162$, paragraph 18). Annan's response, issued in September 2001 as the Road Map towards the Implementation of the United Nations Millennium Declaration, proposed the eight MDGs in their final form and by that name (General Assembly document A/56/326), drawing only on elements to which 147 heads of state or government had directly agreed at the 2000 summit.

${ }_{4}^{3}$ www.developmentgoals.org

${ }^{4}$ The leaders gathered at the Millennium Summit committed only to halving global poverty, regardless of what happens in any given country or region. They never agreed that each country or region would individually halve poverty by 2015, though the first MDG has often been given this latter interpretation. The UN's Human Development Report 2003 (pp. 198-202) and the World Bank's World Development Report 2004 (pp. 254-255), for example, both track individual countries' progress towards halving national poverty by 2015 as indicators of progress towards the first MDG.

${ }^{6}$ See, e.g., "Donors fail on education funding”, by Andrew Balls, Financial Times, March 29, 2004.

7 "Donors" is used here to signify the 23 members of the OECD's Development Assistance Committee. All ODA data comes from the DAC.

${ }^{8}$ For more background on the origins of the MDGs, see Devarajan 2002, pp. 4-5.

${ }^{9}$ Since 1970 the UN has had an explicit goal to raise ODA to $0.7 \%$ of GNI. The origin of the aid target was the 1969 Pearson Commission report, later accepted by the DAC and then endorsed by the UN General Assembly in October 1970.

${ }^{10}$ OECD, http://www.paris21.org/betterworld

${ }^{11} \mathrm{http} / / / \mathrm{www} . \mathrm{hm}-$ treasury.gov.uk/documents/international_issues/int_gnd_intfinance.cfm

${ }^{12}$ See, for example, the UNDP (http://www.undp.org/mdg/faqs.html), Jubilee 2000 (Greenhill 2002), and Oxfam (2002).

${ }^{14}$ Other problems with the static unit cost technique, as Devarajan has observed, include the fact that it guides more aid to those countries where costs are highest—-that is, those who will use the aid least efficiently—creating an incentive for even greater inefficiency.

${ }^{15}$ From a note written by Brown for BOND, a network of development NGOs in the UK (http://www.bond.org.uk/networker/june03/gbrown.htm). Three examples of newspaper reports and opinion pieces that discuss dollar amounts to meet the MDGs but fail to mention the need for policy reform in developing countries or aid reform in the developed world as part of the package: "Stubborn Debt Burden Spurs Search for New Ideas” Warren Vieth, Los Angeles Times 23 April 2004; "Brown Wants Alliance of Rich to Lift Africa” Carl Mortished The Times 17 February, 2004. There are innumerable others.

${ }^{16}$ Bhalla (2002) claims this has been reached already, but the World Bank disputes this (see World Bank, 2004b). 
${ }^{17}$ Gottschalk (2000) estimates an even required higher rate of 8.2\% for sub-Saharan Africa and $10.2 \%$ for Latin America.

${ }^{18}$ See Mosley et. al. (2004), Dalgaard et. al. (2004), Easterly et al. (1993); Sachs (1996), Sachs (1997); Easterly (2003b); Kenny (1999). See also Kenny and Williams (2001) for a review of the weak link between long-term growth and indicators covering trade, monetary, fiscal, industrial and social policies.

${ }^{19}$ Although Devarajan et. al suggest that, using the coefficients from Collier and Dollar, the \$50 billion additional aid they suggest could be apportioned only hitting this binding constraint in two countries. Furthermore, if aid were better delivered by donors, this binding constraint might be even higher.

${ }^{20}$ And neither may want considerably more ODA. India recently announced that it was restricting its aid receipts to only six countries (Marcelo, 2003).

${ }^{21}$ It is also worth briefly mentioning here the second half of MDG Goal One, which aims to halve the number of people suffering from hunger. While data weaknesses do not allow a detailed analysis of the likelihood of this target being reached, FAO data do suggest that progress can be rapid in reducing hunger. Fifty-eight developing countries saw declining malnutrition rates over the 1990s, with an average decline of 25 percent. However, at the same time, the unweighted average showed a decline of just two percent a result of significant malnutrition increases in some countries, such as Iraq. Furthermore, progress was slow in some large countries, such as China's decline in malnutrition rates from 16 to 9 percent, India's reduction from 25 to only 24 percent, and Brazil’s drop from 13 to 10 percent

${ }^{22}$ Even if one accepts a close link between improvements in social sector performance and income growth, the rates of income growth required to meet MDG social targets are historically unprecedented -using cross-country variations in child mortality and income in 2000 to calculate elasticities suggests that low income countries would have to grow at $6.7 \%$ a year to reduce mortality by two thirds in 2015 (World Bank, 2004b).

${ }^{23}$ For example, Devarajan et al. (2002) use four different measures to calculate a range of \$10.4-27.6 billion and Mingat et al. (2002) admit the unit cost approach is unreliable because it "ignores the dynamics of population and enrollment growth” (p, 30).

${ }^{24}$ This section is substantially based on Clemens (2004).

${ }^{25}$ The second MDG specifically refers to primary school completion rates, but in this section we discuss enrollment rates. This is because there are few historical data on completion rates. If anything, this change provides bias in the direction of meeting the goals more quickly, since completion takes longer than enrollment and enrollment is, by definition, an upper bound on completion. For more explanation, see Clemens (2004).

${ }^{28}$ In 2000, the World Development Indicators 2004 lists data for 131 countries on the ratio of girls to boys in primary and secondary education. Of those countries in that year, only ten remained below the level of 80 girls per 100 boys.

${ }^{29}$ Various estimates of the cost for universal primary education are based on unit spending per child times the number of out-of-school children. The Delamonica et al. (2001) study for Unicef, for example, takes the net enrollment ratio and calculates the cost of raising this gradually to $100 \%$ by 2015 . It adjusts for country variances by allowing a country-by-country unit cost, based on a constant ratio of per capita income, but assumes zero per capita income growth over the 15-year period. Thus, there is no connection in the Unicef model between education and changes in the wider economy-even though the evidence suggests that such factors are very important.

${ }^{30}$ The fourth MDG is defined in terms of child mortality. The analysis presented in Figures 5 and 6 uses infant mortality instead, since available infant mortality statistics extend much further back in time than do child mortality statistics. This is immaterial to our discussion, since the rates of change of infant and child mortality tend to track each other closely across countries.

${ }^{31}$ This figure is not strictly comparable with the above figure for the whole $20^{\text {th }}$ century, since the sample of countries is quite different and the post-1980 figure includes far more poor countries.

${ }^{32}$ The same holds true for related measures to MMR such as the percentage of births attended by a skilled health care worker (AbouZahr and Wardlaw 2001).

${ }^{33}$ In the case of access to clean water (where the MDG target is to halve the number without access), there are also indications that rapid progress can be achieved. WHO and UNICEF have data on the percentage of population lacking access in 1990 and 2000 for sixty countries where access in 1990 was not already at $100 \%$. Looking at those countries, the average change was a 21 percent drop in the percentage without access and seventeen countries managed to slash the figure by more than $30 \%$ (just seven saw 
deterioration). Further, it appears that almost as many countries with low initial access scores saw rapid improvement as did countries already close to universal clean water access in 1990. WHO and UNICEF's 1990 and 2000 data covering 63 developing countries where access to sanitation was not at 100 percent in 1990, suggests again that the picture regarding this target may also be positive. The average decline in those lacking access was 19.5 percent. Only three countries saw a rise in the percentage lacking access, compared to 18 who saw a fall greater than 30 percent. While progress can be rapid in some areas, however, Fay and Yepes (2003) suggest that 93 percent of the variation across countries in access to sanitation can be explained by income, share of agriculture in GDP and (most significantly) urbanization, suggesting that progress towards the MDG targets may have been historically more significantly influenced by structural changes than aid flows. Data vailable at http://millenniumindicators.un.org/unsd/mi/mi_goals.asp

${ }^{34}$ Although, looking at determinants of malaria infection rates, McCarthy et al. (2000) calculate that weather, latitude, income, poverty and inequality account between them for 4.9 times the variation in infection rates than does access to rural health care (even though this does suggest some role for government expenditure and aid, see also Mills and Shillcutt, 2004).

${ }^{37}$ We thank Shanta Devarajan for suggesting this expository device. 